\title{
A Newly Established Murine Cell Line as a Model for Hepatocellular Cancer in Non-Alcoholic Steatohepatitis
}

\author{
Andreas Kroh ${ }^{1, *,+} \mathbb{D}$, Jeanette Walter ${ }^{1, \dagger}{ }^{,}$Herdit Schüler ${ }^{2}$, Jochen Nolting ${ }^{1}{ }^{\mathbb{D}}$, Roman Eickhoff ${ }^{1}$, \\ Daniel Heise ${ }^{1}\left(\mathbb{D}\right.$, Ulf Peter Neumann $1,3,4,5$, Thorsten Cramer ${ }^{1,3,4,5}$, Tom Florian Ulmer ${ }^{1,3}$ and \\ Athanassios Fragoulis 1,6 \\ 1 Department of General, Visceral and Transplantation Surgery, Uniklinik RWTH Aachen, 52074 Aachen, \\ Germany; jeanette.walter@rwth-aachen.de (J.W.); jnolting@ukaachen.de (J.N.); reickhoff@ukaachen.de (R.E.); \\ dheise@ukaachen.de (D.H.); uneumann@ukaachen.de (U.P.N.); tcramer@ukaachen.de (T.C.); \\ fulmer@ukaachen.de (T.F.U.); afragoulis@ukaachen.de (A.F.) \\ 2 Institute of Human Genetics, Uniklinik RWTH Aachen, 52074 Aachen, Germany; hschueler@ukaachen.de \\ 3 Department of Surgery, Maastricht University Medical Center, 6200 MD Maastricht, The Netherlands \\ 4 ESCAM-European Surgery Center Aachen Maastricht, 52074 Aachen, Germany \\ 5 ESCAM-European Surgery Center Aachen Maastricht, 6200 MD Maastricht, The Netherlands \\ 6 Department of Anatomy and Cell Biology, Uniklinik RWTH Aachen, 52074 Aachen, Germany \\ * Correspondence: akroh@ukaachen.de; Tel.: +49-241-80-89-501 \\ + These authors contributed equally to this work.
}

Received: 22 October 2019; Accepted: 8 November 2019; Published: 12 November 2019

\begin{abstract}
Non-alcoholic steatohepatitis (NASH) has become a major risk factor for hepatocellular cancer (HCC) due to the worldwide increasing prevalence of obesity. However, the pathophysiology of NASH and its progression to HCC is incompletely understood. Thus, the aim of this study was to generate a model specific NASH-derived HCC cell line. A murine NASH-HCC model was conducted and the obtained cancer cells (N-HCC25) were investigated towards chromosomal aberrations, the expression of cell type-specific markers, dependency on nutrients, and functional importance of mTOR. N-HCC25 exhibited several chromosomal aberrations as compared to healthy hepatocytes. Hepatocytic (HNF4), EMT (Twist, Snail), and cancer stem cell markers (CD44, EpCAM, CK19, Sox9) were simultaneously expressed in these cells. Proliferation highly depended on the supply of glucose and FBS, but not glutamine. Treatment with a second generation mTOR inhibitor (KU-0063794) resulted in a strong decrease of cell growth in a dose-dependent manner. In contrast, a first generation mTOR inhibitor (Everolimus) only slightly reduced cell proliferation. Cell cycle analyses revealed that the observed growth reduction was most likely due to $G_{1} / G_{0}$ cell cycle arrest. These results indicate that N-HCC25 is a highly proliferative HCC cell line from a NASH background, which might serve as a suitable in vitro model for future investigations of NASH-derived HCC.
\end{abstract}

Keywords: non-alcoholic steatohepatitis; hepatocellular carcinoma; cell line; mTOR; Everolimus; KU-0063794

\section{Introduction}

Hepatocellular carcinoma (HCC) is the third leading cause of cancer-related deaths worldwide [1]. Therapeutic options vary from surgical therapy and percutaneous ablation under curative intent to cytostatic therapy and transarterial chemoembolisation (TACE) under palliative intent [2-4]. The majority $(70 \%)$ suffers from metastasis or de novo HCC, despite a five-year survival rate of $70 \%$ in patients with a curative treatment strategy [5-8]. The high recurrence rate of HCC is especially based on the survival of cancer stem cells (CSCs), which are a subpopulation of cells that are resistant to chemotherapy and radiation [9]. Therefore, CSCs are a current focus in HCC research. Non-alcoholic 
steatohepatitis (NASH) has become the most frequent cause of HCC [10] due to the rapid increase of obesity in the past decades and available therapies for the other relevant $\mathrm{HCC}$ risk factors hepatitis $\mathrm{C}$ and B (HCV and HBV) [11,12]. The development of both HBV/HCV- as well as NASH-derived HCC is not yet fully understood. Although they share some common hallmarks (inflammation, fibrosis, cirrhosis), the pathogenesis and outcome still differ in several aspects. By escaping the HLA-II-mediated immune response, $\mathrm{HBV} / \mathrm{HCV}$ infects hepatocytes, whereby oxidative stress and the subsequent recruitment of inflammatory cells activate hepatic stellate cells (HSC) and collagen deposition. Besides, several HCV proteins are also known to induce fibrogenic and inflammatory processes of HSCs [13,14]. In viral hepatitis, initial fibrosis mostly develops within portal tracts, which leads to persistent portal inflammation, cirrhosis, and ultimately HCC. In contrast, dyslipidaemia, a commonly observed phenomenon in obese patients suffering from non-alcoholic fatty liver disease (NAFLD), leads to increased hepatic lipid deposition (steatosis) and more generalized liver inflammation. This, in turn, triggers a copious development of liver fibrosis, which causes NASH that can advance to HCC either via cirrhosis or without. [15-18]. However, NASH occurs not only in obese, but also in non-obese patients [15], which indicates a multifactorial genesis. Besides fibrosis, the typical hallmarks of $\mathrm{NASH}$-derived HCC in patients are metabolic changes, such as weight gain, insulin resistance, diabetes mellitus, and triglyceridemia, as well as histopathological changes, such as hepatocyte ballooning, steatosis, lobular inflammation, and Mallory Denk bodies [19]. So far, the therapeutic options include lifestyle modification, treatment with vitamin E or pioglitazone, as well as bariatric surgery $[20,21]$. While the required weight loss of $10 \%$ for the reduction of inflammation and fibrosis is difficult to achieve, treatment with vitamin $\mathrm{E}$ and pioglitazone failed to reduce fibrosis and displays numerous long-term side effects. Currently, several clinical phase II/III trails are evaluating the benefit of e.g., antifibrotic, lipidaltering-, and anti-inflammatory targets [21].

Suitable in vitro models are needed in order to enable the investigation of NASH-derived HCCs. In this study, we provide a highly proliferative hepatocellular cancer cell line from mice with NASH-derived HCC, named N-HCC25. As HCC is a highly heterogeneous cancer type [22], it was essential to characterize the newly isolated cell line regarding chromosomal aberrations, expression of cell type-specific markers, cell metabolism, and growth. The dependency of N-HCC 25 on nutrients was explored, as the metabolism of glucose, glutamine and fetal bovine serum (FBS) are currently discussed as targets for future HCC therapy [23-26]. As the mechanistic target of rapamycin (mTOR) is a major regulator of cell growth and metabolism, which is upregulated in $40-50 \%$ of HCCs [27-29], it is frequently addressed in HCC research [30]. While mTOR complex 1 (mTORC1) responds to nutrients, growth factors, stress, energy status, and amino acids, mTOR complex 2 (mTORC2) only responds to growth factors and is insensitive to nutrients. mTORC1 promotes cell growth, cell cycle progression, metabolism, protein biosynthesis, lipogenesis and negatively regulates autophagy [31]. Besides metabolism and cell growth, mTORC2 is mainly involved in cell survival $[32,33]$ and cytoskeletal organization $[34,35]$. First generation mTOR inhibitors, also known as rapalogs, suppress mTORC1; second generation inhibitors block either mTORC1/mTORC2 or mTORC1/PI3K. Despite a significant anti-proliferative effect in preclinical studies [36,37] and success in the therapy of other solid tumors [38], no survival benefit was shown for single agent first generation inhibitor treatment of HCC in clinical studies [39]. Currently, these rapalogs are being investigated in combination with other drugs in patients with advanced HCC [38]. In contrast, second generation inhibitors have shown a stronger cytotoxic effect than rapalogs in preclinical studies [40-44]. In this study, the first generation inhibitor Everolimus and the second-generation inhibitor KU-0063794 were used to investigate the effect of mTOR inhibition on NHCC25. While Everolimus currently serves as an additive in clinical studies for advanced HCC and as adjuvant therapy in HCC patients after liver transplantation or TACE to prevent HCC recurrence [38], the growth inhibiting effects of the highly specific mTORC1/mTORC2 inhibitor KU-0063794 [45] were shown for HepG2 both in vitro and in vivo [46]. As investigation of NASH-derived HCC is required for sufficient future HCC therapy, we provide a new isolated and characterized HCC cell line from a murine NASH-HCC model. 


\section{Results}

\subsection{Isolation of N-HCC25 Cell Line}

A modified version of the mouse model originally described by Yoshimoto, Loo et al. [47] was used to investigate NASH-derived HCC on a cellular level (Figure 1a). The treated animals displayed characteristic pathological changes, as also seen in human NASH-HCC, such as significant weight gain, insulin resistance, and glucose intolerance (data not shown). NASH was further confirmed by histopathological evaluation with both NAS (NASH-HCC $=4$ compared to 7,12-Dimethylbenz[a]anthracene (DMBA) control =1) [48] and SAF (NASH-HCC $=6 \mathrm{~S}_{2} \mathrm{~A}_{2} \mathrm{~F}_{2}$ compared to $\mathrm{DMBA}$ control $=1 \mathrm{~S}_{0} \mathrm{~A}_{1} \mathrm{~F}_{0}$ ) [49] Score (as is used in the human situation). Representative images of H\&E, PAS as well as Sirius Red staining are shown in the supplementary material (Figure S1). The occurring tumours were visible macroscopically and detectable via in vivo $\mu$ CT (Figure 1b). After 34 weeks, the N-HCC25 cells were isolated from the liver. Figure 1c shows representative pictures of early and late passages of N-HCC25 cells.

a

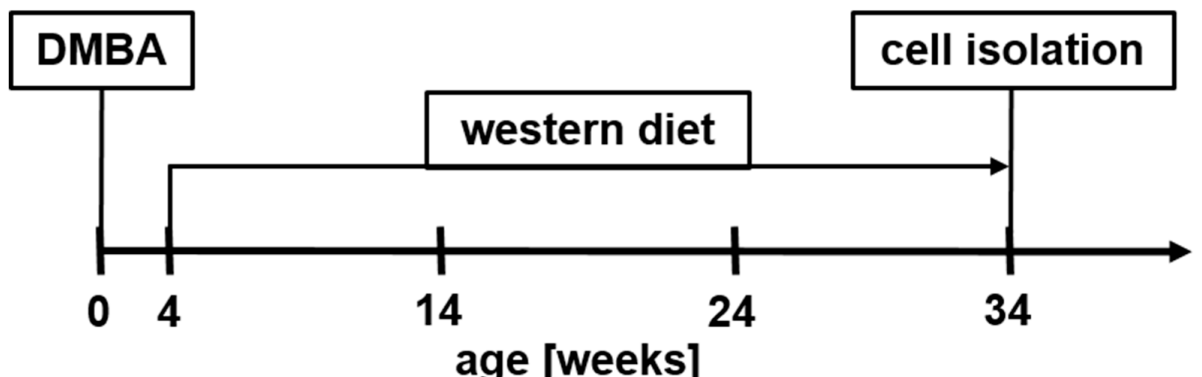

b
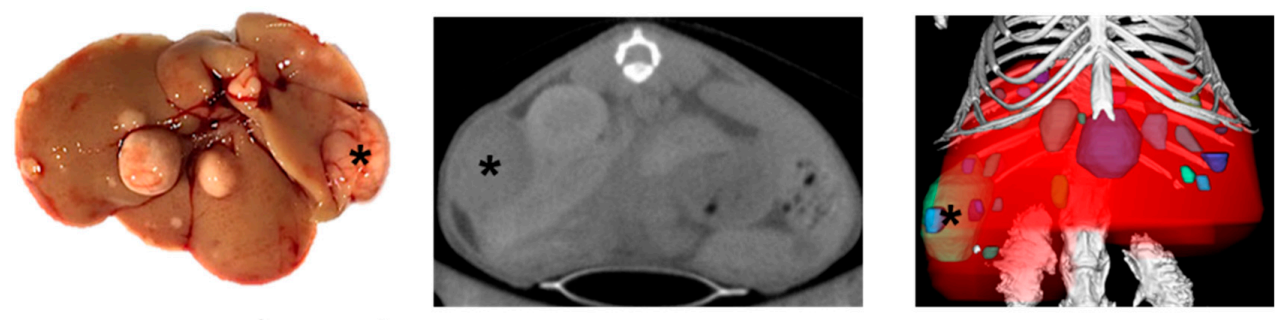

c

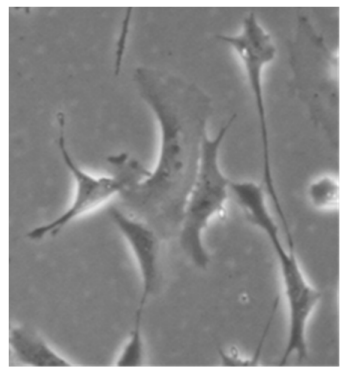

P4

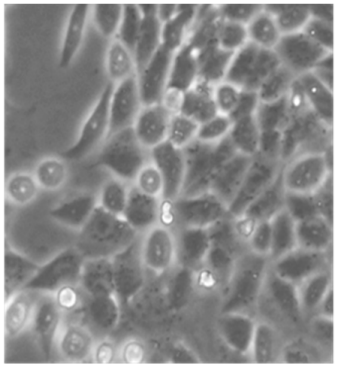

P16

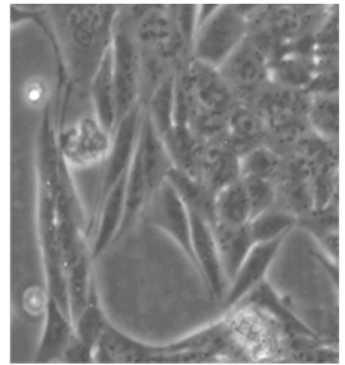

P24

Figure 1. Isolation of N-HCC25 cell line. (a) Male C57BL/6 mice were treated with 7,12-Dimethylbenz [a]anthracene (DMBA) on the 4th postnatal day and fed western diet for 30 weeks to develop hepatocellular cancer in NASH; (b) Characteristic picture of liver tissue that was used for isolation of N-HCC25 (view from dorsal, scale $=1 \mathrm{~cm}$ ). Two-dimensional (2D) cross-sectional $\mu \mathrm{CT}$ image (transversal) of the mouse. 3D volume renderings of segmented bones (white), liver (red) and tumors (different colour for each tumor) upon in vivo $\mu \mathrm{CT}$ imaging (tumor marked with black asterisk, " $\mathrm{R}$ " marks right side of liver or mouse, scale $=1 \mathrm{~cm}$ ); (c) Representative pictures from early and late passages of N-HCC25 (scale $=50 \mu \mathrm{m})$. 


\subsection{N-HCC25 Cells Exhibit Chromosomal Aberrations Associated with HCC Pathology}

The origin of N-HCC25 cells was studied via cytogenetic analyses comparing primary hepatocytes and N-HCC25 cells. Our results demonstrate that primary murine hepatocytes were all diploid (Figure S2a), while NHCC25 were polyploid and they accumulated chromosomal instability to a considerable extent.

The number of chromosomes decreased with the number of cell culture passages, whereby certain chromosomes or chromosomal segments remained relatively stable (e.g., MMU X D-F4, 1 A-F, 11 B-E2, 6, 8), while others seemed to be preferentially eliminated (e.g., MMU Y, 3, 4, 7, 10, 14, 18) (Table 1).

Table 1. Numerical aberrations identified by cytogenetic approaches. Frequency of aneuploidies (tetrasomy and reduction to disomy) are shown in the upper part and general ploidy grades of investigated passages (P3 \& P29) in the lower part of the table.

\begin{tabular}{|c|c|c|c|c|}
\hline \multirow{2}{*}{ Chromosome } & \multicolumn{2}{|c|}{ Aneuploidy $(4 \times)$} & \multicolumn{2}{|c|}{ Loss of Additional Chromosomes (2x) } \\
\hline & P3 & $\mathbf{P} 29$ & P3 & P29 \\
\hline 2 & $95 \%$ & $4 \%$ & - & $8 \%$ \\
\hline 3 & $60 \%$ & - & $10 \%$ & $50 \%$ \\
\hline 4 & $30 \%$ & $4 \%$ & $10 \%$ & $85 \%$ \\
\hline 5 & $75 \%$ & - & - & $15 \%$ \\
\hline 6 & $45 \%$ & $54 \%$ & - & $4 \%$ \\
\hline 7 & $50 \%$ & $4 \%$ & $20 \%$ & $88 \%$ \\
\hline 8 & $70 \%$ & $38 \%$ & - & - \\
\hline 9 & $55 \%$ & $4 \%$ & $5 \%$ & $31 \%$ \\
\hline 10 & $35 \%$ & - & $15 \%$ & $81 \%$ \\
\hline 11 & $25 \%$ & - & - & - \\
\hline 12 & $65 \%$ & $19 \%$ & - & $8 \%$ \\
\hline 13 & $20 \%$ & - & $5 \%$ & $38 \%$ \\
\hline 14 & $30 \%$ & - & - & $58 \%$ \\
\hline 15 & $15 \%$ & $8 \%$ & - & $8 \%$ \\
\hline 16 & $25 \%$ & $19 \%$ & - & $11 \%$ \\
\hline 17 & $5 \%$ & - & - & $8 \%$ \\
\hline 18 & - & - & $50 \%$ & $46 \%$ \\
\hline \multirow[t]{2}{*}{19} & $15 \%$ & $15 \%$ & $15 \%$ & $4 \%$ \\
\hline & ploidy grade & \#chromosomes & range & \\
\hline P3 & hypo-tetraploid & 65 & $60-69$ & \\
\hline P29 & hypo-triploid & 56 & $50-59$ & \\
\hline
\end{tabular}

The degree of polyploidy of the cells could not be determined with certainty, but it was presumed that the majority of cells probably had a tetraploid state. In the early cell culture passage, the average number of chromosomes was 65 (based on 25 mitoses, range: 60-69 chromosomes) with penta- and tetrasomeric status (5- and 4-fold occurrence, respectively) of several chromosomes. In the later passage, the average number of chromosomes decreased to 56 (26 mitoses, range 50-59), whereby $12 \%$ of the cells revealed no (penta- or) tetrasomic status of any chromosome.

Besides the changes in copy number and an aneuploidy rate of $100 \%$ in the cells of early and late passage, recurrent rearrangements, which become stable during time (passages), were also observed (Figure 2a-d, Table 2).

An unbalanced translocation between chromosome 1 and 11 with breakage at band $1 \mathrm{~F}$ and band $11 \mathrm{~B}$, respectively, was found. This aberration was finally detected in every metaphase, which resulted in copy number gain of the segment $11 \mathrm{~B}-\mathrm{E} 2$.

By molecular cytogenetic (FISH) analyses, an unbalanced X-autosome translocation of one of the $\mathrm{X}$ chromosomes with involvement of the segment A2 to $\mathrm{F} 3$ of chromosome 15 was detected. A possible spreading-of-inactivation of the $\mathrm{X}$ chromosome might silence a portion of the adjacent autosomal segment of chromosome 15. 
In the early passage, $73 \%$ of the cells had a Robertson fusion between one of the chromosomes 16 and 19 (Rb16.19), which formed a metacentric chromosome. The proportion of cells with Rb.16.19 rose to $86 \%$ in the later passage. Robertson fusions involving chromosome 19 are rarely observed. This underrepresentation of chromosome 19 is attributed to the particular gene endowment in the proximal region.

A deletion of chromosome 17 (Del (17)) was consistently detectable in the cells of the late passage 29 and it caused a loss of the segment E1-E5.

FISH analyses uncovered the loss of the $\mathrm{Y}$ chromosome in $44 \%$ and $55 \%$ of the cells, respectively. However, a significant portion of interphase nuclei showed a marked amplification of the Y chromosome (Figure S2b).

A list of the genes that may be affected by the above-mentioned aberrations, including tumordrivers/oncogenes (gain-of-function), tumour-suppressors (loss-of-function), as well as microRNAs (both), are supplied in the supplementary File S1 (Excel file).

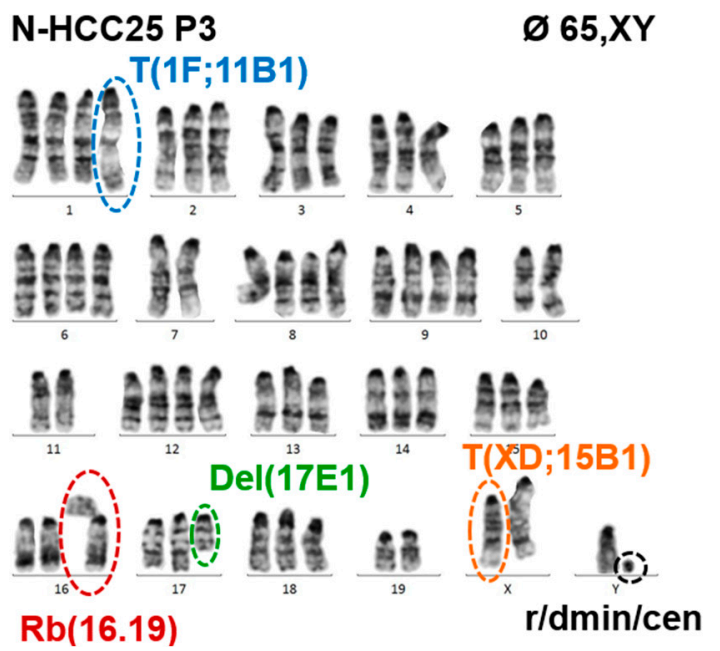

C

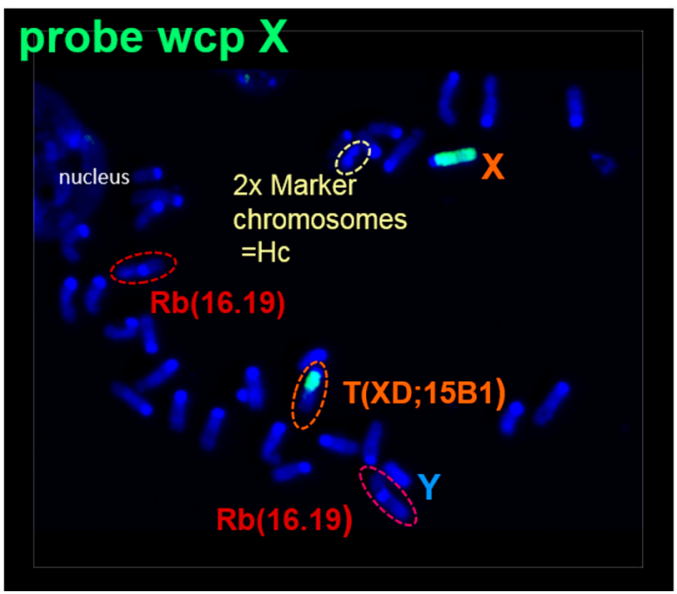

b

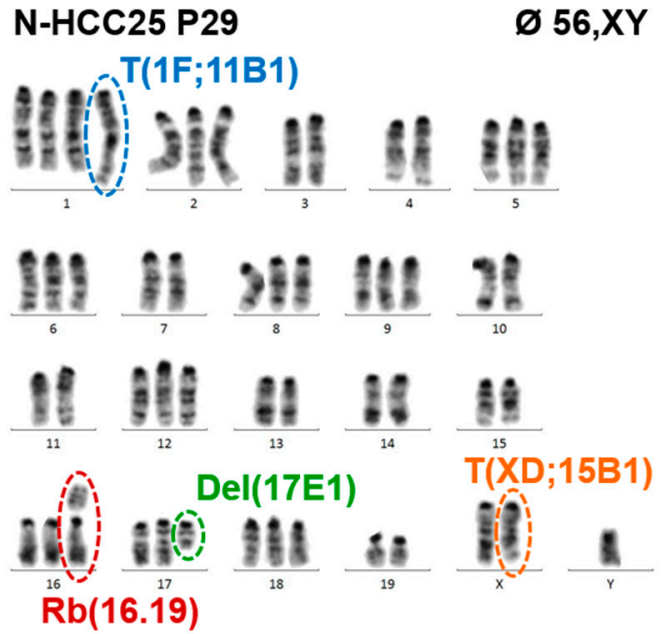

d

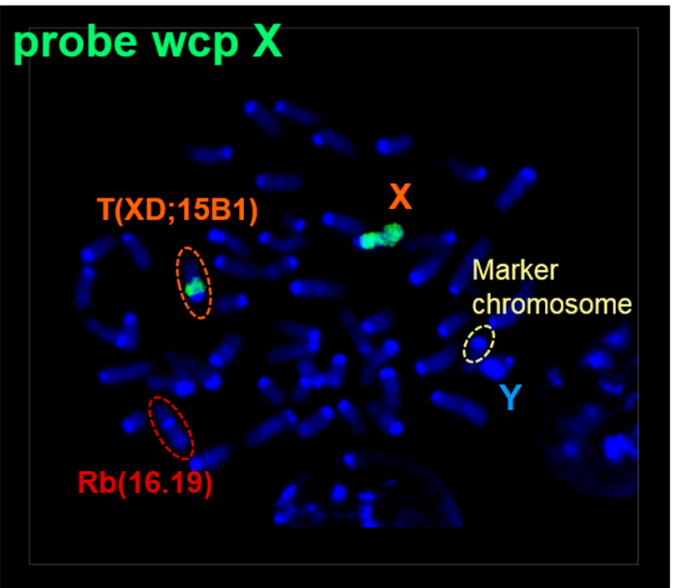

Figure 2. N-HCC25 cells display structural and numerical chromosomal aberrations associated with HCC pathology. Karyograms of N-HCC25 cells, (a) early passage 3 and (b) late passage 29. Fluorescence in situ hybridisation (FISH, whole-chromosome-painting probe $\mathrm{X}$ for $\mathrm{X}$-chromosomal DNA content of early $(\mathbf{c})$ and late $(\mathbf{d})$ passage (magnification $=1200 \times)$. $\mathrm{T}=$ unbalanced translocation; $\mathrm{Rb}=$ Robertsonian Fusion; Del = Deletion; Hc $(\mathrm{r} / \mathrm{dmin} / \mathrm{cen})=$ pericentric heterochromatin; $\mathrm{wcp}=$ whole chromosome painting probe. Detailed information about aberration are shown in brackets. 
Table 2. Structural aberrations identified by cytogenetic approaches. Frequency of structural aberrations and chromosomal rearrangements. $\mathrm{T}=$ unbalanced translocation; $\mathrm{Rb}=$ Robertsonian Fusion; Del = Deletion; $\mathrm{r} / \mathrm{dmin} / \mathrm{cen}=$ pericentric heterochromatin.

\begin{tabular}{ccc}
\hline Kind of Aberration & P3 & P29 \\
\hline T (1F;11B1) & $96 \%$ & $100 \%$ \\
Rb 16.19 & $73 \%$ & $86 \%$ \\
Del(17E1) & $92 \%$ & $100 \%$ \\
T (XD;15B1) & $82 \%$ & $93 \%$ \\
loss of Y & $44 \%$ & $55 \%$ \\
r/dmin & $48 \%$ & $61 \%$ \\
\hline
\end{tabular}

\subsection{N-HCC25 Cells Derive from Hepatocytes and Express Cancer-Related Markers}

The origin and characteristics of N-HCC25 were further explored on the transcriptional level in absence/presence PCR experiments (Figure 3). Early and late passages were analyzed to include early changes in gene expression. While N-HCC25 cells did not show expression of Albumin as a basic marker for hepatocytes, the gene expression of HNF4 was still found in the early passages P5-10. Specific HCC tumor markers, such as CK19, Sox9, and EpCAM, were expressed in all analyzed passages. Moreover, P5-24 showed the expression of CD44, which is known as a common cancer stem cell marker. The epithelial mesenchymal transition markers Twist and Snail were also expressed in all of the observed passages of N-HCC25.

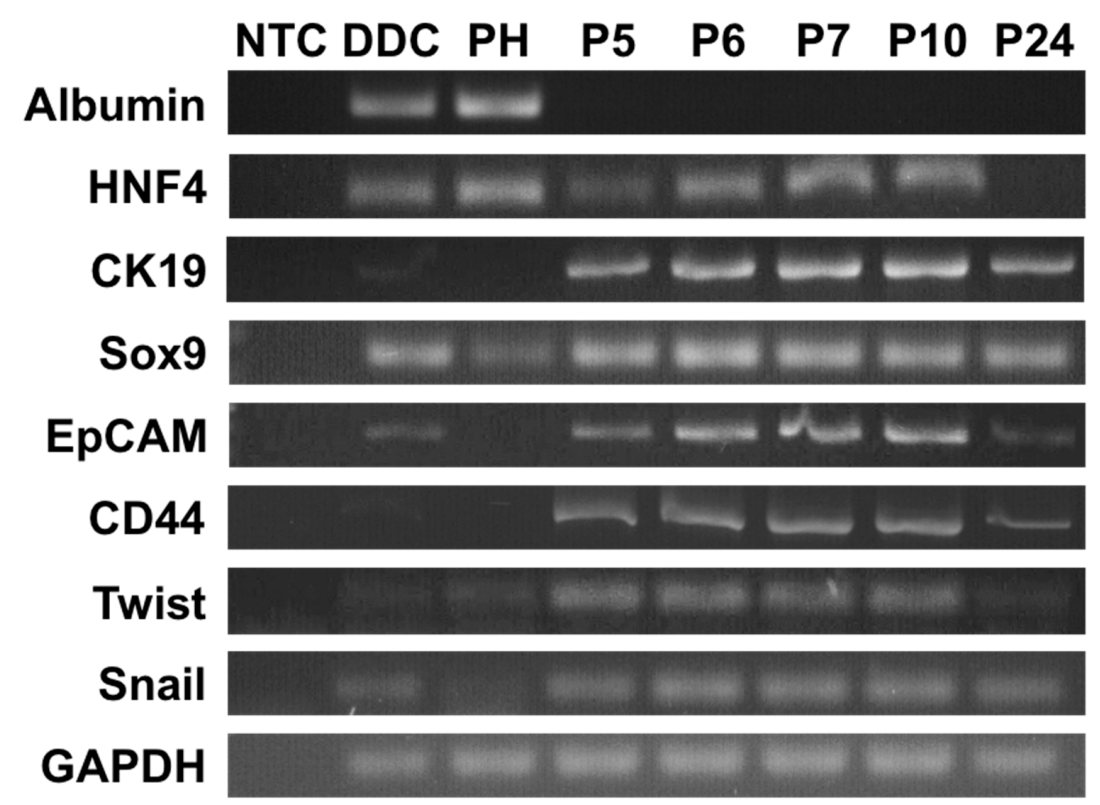

Figure 3. N-HCC25 cells derived from hepatocytes and express tumor-like gene markers. RNA was isolated and transcribed in cDNA for various passages $(\mathrm{P})$ of N-HCC25 cells. PCR was conducted with specific markers of hepatocytes (Albumin, HNF4), cancer stem cells (CK19, Sox9, EpCAM, CD44) and epithelial-mesenchymal transition (Twist, Snail). GAPDH served as reference gene. No template control (NTC) served as negative control; liver samples from DDC treated mice (DDC) and primary hepatocytes $(\mathrm{PH})$ served as positive controls.

\subsection{Growth of N-HCC25 Cells Mostly Depends on Sufficient Levels of Glucose and FBS}

In tumor cells, the availability of basic nutrients plays an important role for metabolism and proliferation. In starvation experiments of $\mathrm{N}-\mathrm{HCC} 25$, no statistically significant effects were found after an incubation time of $24 \mathrm{~h}$ with reduced glutamine, FBS, or glucose levels (Figure $4 \mathrm{a}-\mathrm{c}$ ). In contrast, a significant decrease in cell count was observed in cells that were cultured with $0.5 \mathrm{~g} / \mathrm{L}$ and $0 \mathrm{~g} / \mathrm{L}$ 
glucose for $48 \mathrm{~h}$ (Figure 4c). Equally, the cell count was significantly reduced in cells that were cultured in FBS- or glutamine-free culture medium for $48 \mathrm{~h}$ (Figure $4 \mathrm{a}, \mathrm{b}$ ). The effect of starvation was further investigated by $x$ CELLigence real-time cell analyzer (RTCA) that enables the longitudinal measurement of cell density in real-time. During cell adherence, no differences in proliferation occurred between the experimental groups (Figure 4d,e, phase I; Figure 4f, $\mathrm{t}_{1}$ ). Full medium control (FM) and cells that were cultured in reduced glutamine initially showed rapid proliferation until reaching a plateau $48 \mathrm{~h}$ after stimulation (Figure 4d, phase II), as indicated by high slopes and cell index (CI) (Figure 4e,f, phase II or $t_{2}$ resp., 1st and 2nd column). In comparison, the treatment of N-HCC25 cells with reduced FBS and glucose resulted in a lower proliferation index (Figure $4 \mathrm{~d}-\mathrm{f}$, phase II or $\mathrm{t}_{2}$ resp., 3rd and 4th column). While treatment with reduced FBS led to a maximum cell density of $2.7 \pm 0.3 \mathrm{CI} 24 \mathrm{~h}$ after stimulation, which lasted until the end of the experiment, (Figure $4 \mathrm{~d}$, phase II-III; $4 \mathrm{f}, \mathrm{t}_{2}-\mathrm{t}_{3}, 3^{\text {rd }}$ column), cells that were treated with reduced glucose initially showed rapid growth followed by a massive decrease in cell density from 36 until $84 \mathrm{~h}$ after stimulation. In phase III, all of the experimental groups showed little cell proliferation (Figure $4 \mathrm{e}$, phase III) and cell indexes of $\mathrm{t}_{3}$ basically corresponded to the values shown in $t_{2}$ (Figure $4 \mathrm{f}$ ).

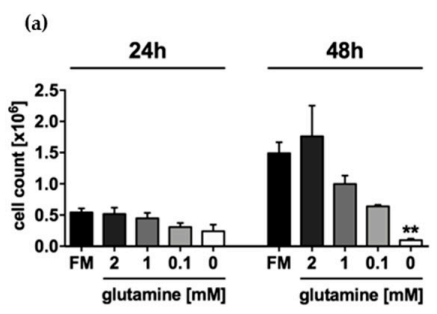

(d)

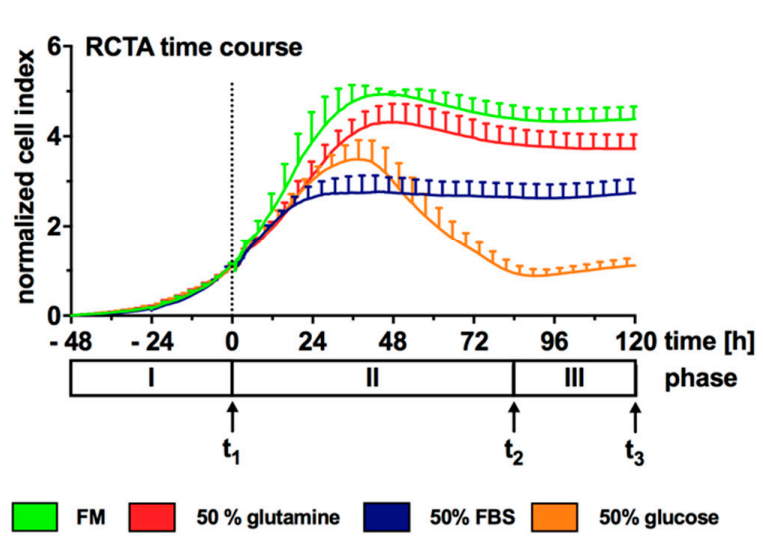

(b)

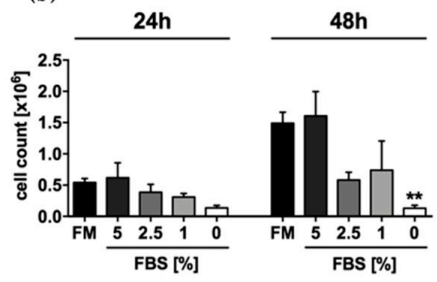

(c)

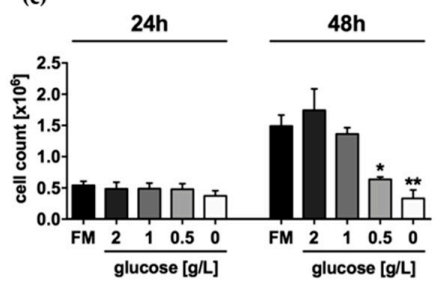

(e)
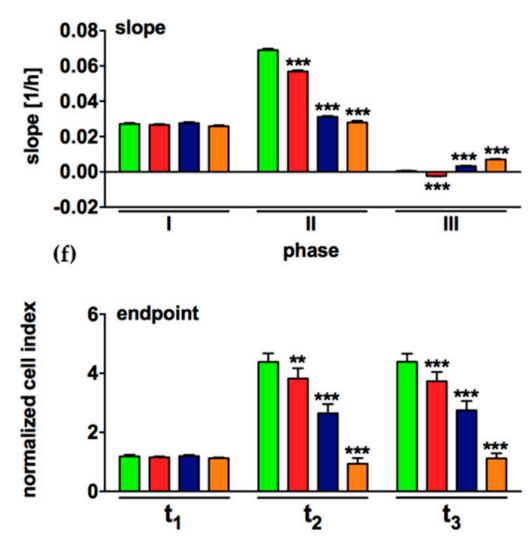

Figure 4. Growth of N-HCC25 cells depends mostly on sufficient levels of glucose and FBS. (a-c) After an adherence phase of $24 \mathrm{~h}, \mathrm{~N}-\mathrm{HCC} 25$ cells were cultured with reduced glutamine, FBS or glucose in various concentrations for 24 and $48 \mathrm{~h}$. Subsequently, cells were counted in Neubauer chamber. (d-f) Starvation experiments were repeated in xCELLigence real-time cell analyzer (RTCA) for longitudinal measurement of cell density. $48 \mathrm{~h}$ after seeding in full medium (FM), cells were treated with halved amounts of glutamine (2 mM), FBS [5 \%] or glucose [2.25 g/L] for $120 \mathrm{~h}$. Data were normalized to the timepoint of stimulation as indicated by the dashed line and grouped into three characteristic phases (I-III). Each phase ends at a respective timepoint $t_{1-3}$. (e) Slope and (f) endpoint were calculated from the data shown in (d). Cells treated with full medium (FM) containing $4 \mathrm{mM}$ glutamine, $10 \%$ FBS and 4.5 $\mathrm{g} / \mathrm{L}$ glucose served as control (a-f). Data represent mean $\pm \mathrm{SEM} ; \mathrm{n} \geq 3$ (starvations of glutamine, FBS \& glucose $\mathrm{n}=3$; FM24h $n=9$ and FM48h $n=10)(\mathbf{a}-\mathrm{c})$; or mean $\pm \mathrm{SD} ; n(\mathrm{FM})=4, n$ (glutamine) $=8$, $n(\mathrm{FBS})=6, n$ (glucose) $=7(\mathbf{d}-\mathbf{f})$. Statistical significances are indicated as ${ }^{*} p<0.05,{ }^{* *} p<0.01$, ${ }^{* * *} p<0.001$ vs. FM control in same phase or timepoint. One-way ANOVA $(\mathbf{a}-\mathbf{c})$ or two-way ANOVA respectively (d-f) with Bonferroni multiple comparison post-hoc test, GraphPad Prism 7 software, La Jolla, CA, USA). 


\subsection{N-HCC25 Cells Exhibit mTOR Activity, which Can Be Blocked by Specific Inhibitors}

The influence of first generation (Everolimus) and second generation (KU-0063794) mTOR inhibitors on the mTOR pathway in N-HCC25 cells was explored, as mTOR is a major regulator of cell growth and a target for pharmacological treatment of HCC in clinical studies. As shown in Figure 5, all experimental groups expressed mTOR. Its autophosphorylation side Ser2481, which is mainly found in the mTOR complex 2, was more phosphorylated in controls and after $6 \mathrm{~h}$ of incubation with Everolimus, but less after $6 \mathrm{~h}$ of treatment with KU-0063794 and $24 \mathrm{~h}$ with both inhibitors. The phosphorylation of mTOR at Ser2448 by AKT serves as a marker for mTORC1 activity. While mTOR was more phosphorylated at Ser2448 in FM and DMSO control, phosphorylation was clearly reduced after treatment with the inhibitors. The rapamycin-insensitive companion of mTOR, named Rictor, was weakly expressed in all of the experimental groups. The expression of GßL (also known as LST8), which is comprised in both mTOR complexes, was shown in all experimental groups, but it was weakly expressed after treatment with Everolimus or KU-0063794 for $24 \mathrm{~h}$. The ribosomal protein S6 and 4E-BP1 are both downstream targets of mTORC1, whose phosphorylation indicates mTORC1 activity. Phosphorylated forms are both only present in FM and DMSO control, but not in cells that were treated with mTOR inhibitors.

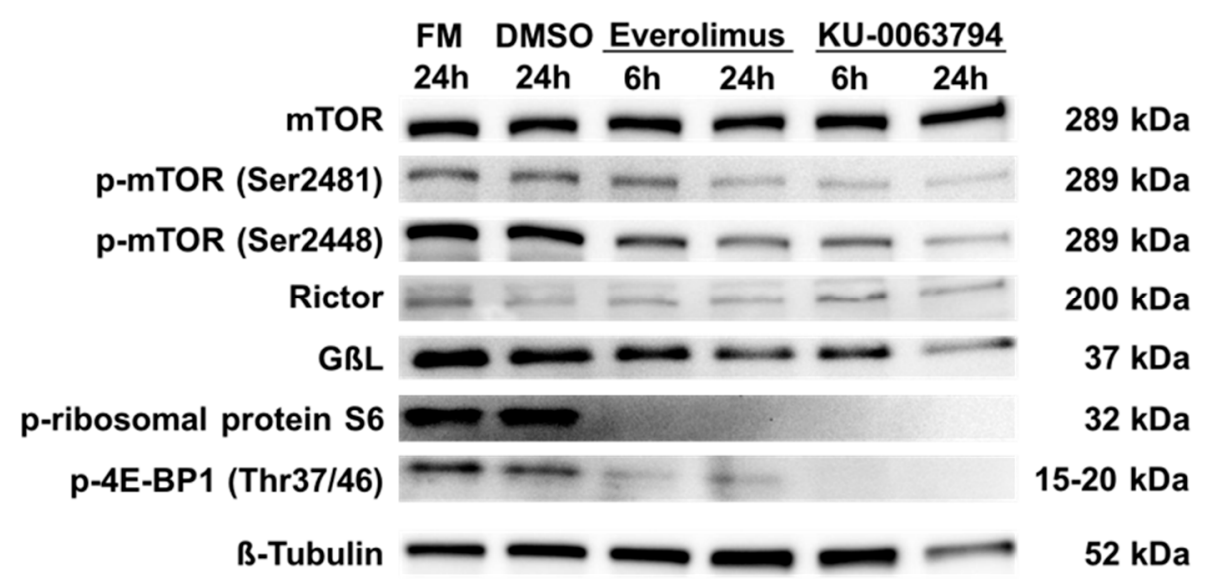

Figure 5. N-HCC25 cells exhibit mTOR activity, which can be blocked by specific inhibitors. The role of mTOR protein pathway in N-HCC25 was analyzed in Western blot including central proteins of mTOR complex 1 and 2 signaling. $42 \mathrm{~h}(24 \mathrm{~h})$ after seeding in full medium (FM), N-HCC25 cells were treated with $2.5 \mu \mathrm{M}$ Everolimus or KU-0063794 for $6 \mathrm{~h}(24 \mathrm{~h})$. Cells cultured in FM with or without $0.025 \%$ DMSO served as controls.

\section{6. mTOR Inhibition Leads to Decreased Proliferation of N-HCC25 Cells}

Next, RTCA was used to compare the effect of Everolimus and KU-0063794 (1, 2.5, and $5 \mu \mathrm{M}$ each) on cell proliferation in a longitudinal manner. During cell adherence, no differences in proliferation were found between the experimental groups (Figure $6 \mathrm{a}-\mathrm{f}$, phase I or $\mathrm{t}_{1}$ resp.). While FM and DMSO control initially showed a high increase of CI (Figure 6a,b, phase II, 1st and 2nd column), cells treated with different concentrations of Everolimus (Figure 6a,b, phase II, 3rd to 5th column) proliferated less than controls. The opposite effect was found in phase III, as indicated by an increased slope in cells that were incubated with the first generation mTOR inhibitor (Figure 6b, phase III, 3rd to 5th column). However, no significant differences were found between the $\mathrm{CI}$ values of the experimental groups at the timepoints $t_{2}$ and $t_{3}$ (Figure 6c). Cells that were treated with KU-0063794 also showed an initially slower growth as compared to FM and DMSO control (Figure 6d, phase II). Treatment with the second generation mTOR inhibitor reduced cell growth in a concentration-dependent manner (6d-f, phase II or $t_{2}$ resp., $3^{\text {rd }}$ to $5^{\text {th }}$ column). In phase III, all of the groups that were treated with KU-0063794 exhibited a faster growth than FM and DMSO control, as indicated by a higher slope (Figure 6e, phase 
III). At both timepoints $t_{2}$ and $t_{3}$, increasing concentrations of the second generation mTOR inhibitor led to a significantly lower cell density as compared to FM control (Figure 6f). The strongest effect was found in treatment with $5 \mu \mathrm{M}$ KU-0063794 (Figure 6f, phase III, $5^{\text {th }}$ column).

(a)

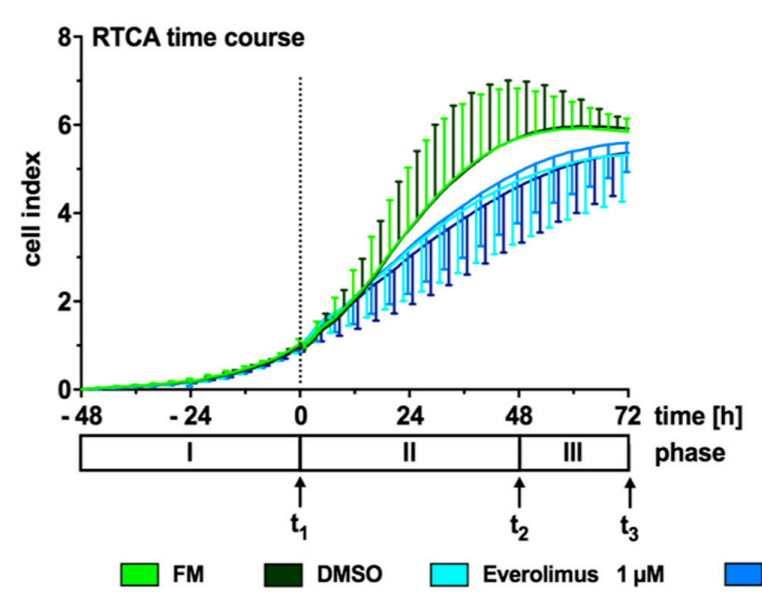

(d)

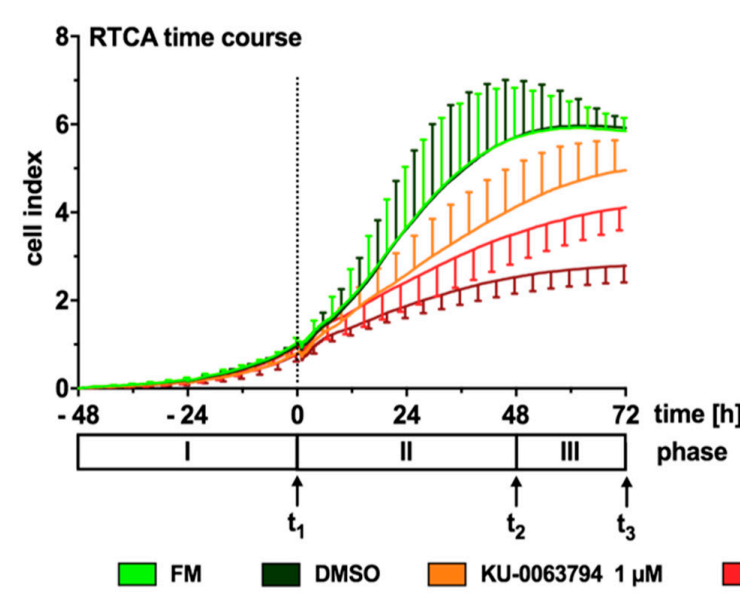

(b)

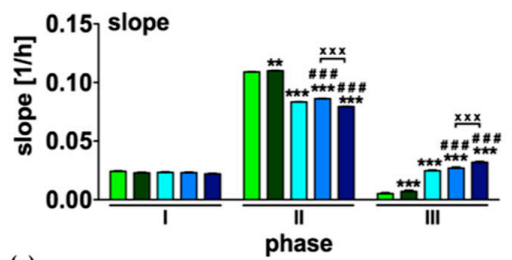

(c)

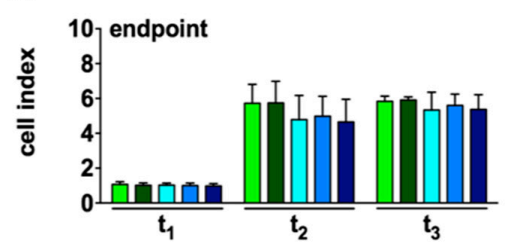

Everolimus $2.5 \mu \mathrm{M} \square$ Everolimus $5 \mu \mathrm{M}$

(e)
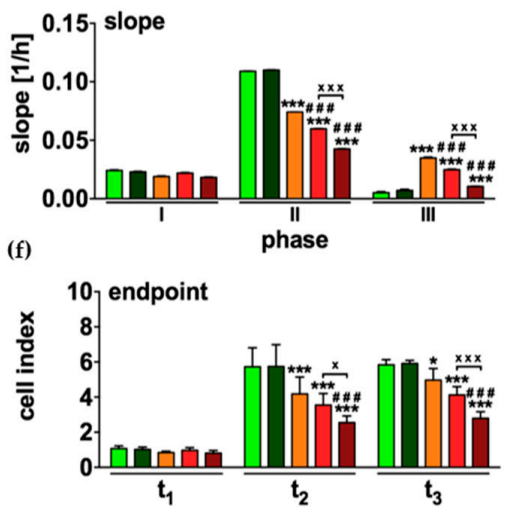

KU-0063794 $2.5 \mu \mathrm{M}$
KU-0063794 $5 \mu \mathrm{M}$

Figure 6. mTOR inhibition leads to decreased proliferation of N-HCC25 cells. Real-time cell analyzer (RTCA) was used to compare the effect of first generation (Everolimus) and second generation (KU-0063794) mTOR inhibition on cell proliferation. $48 \mathrm{~h}$ after seeding, N-HCC25 cells were treated with $1 \mu \mathrm{M}, 2.5 \mu \mathrm{M}$, or $5 \mu \mathrm{M}$ Everolimus $(\mathbf{a}-\mathbf{c})$ or same concentrations of KU-0063794 (d-f). Cell proliferation was recorded for $120 \mathrm{~h}$ in total and grouped into three characteristic phases (I-III). Each phase ends at a timepoint $t_{1-3}$. Slope $(\mathbf{b}, \mathbf{e})$ and endpoint $(\mathbf{c}, \mathbf{f})$ were calculated from the data shown in (a) and (d). Graphs represent mean \pm SD; $n=8$ (KU-0063794 $2.5 \mu \mathrm{M}, n=7)$. Statistical significances are indicated as ${ }^{*} p<0.05,{ }^{* *} p<0.01,{ }^{* * *} p<0.001$ vs. full medium (FM) and DMSO in same phase or timepoint \#\#\# $p<0.001$ vs. $1 \mu \mathrm{M}$ Everolimus or KU-0063794 respectively; $\mathbf{x} p<0.05, \operatorname{xxx} p<0.001$ as indicated. Two-way ANOVA with Tukey's multiple comparison post-hoc test, GraphPad Prism 7 software, La Jolla, CA, USA.

\section{7. mTOR Pathway Inhibition Drives N-HCC25 Cells Into $G_{1} / G_{0}$ Cell Cycle Arrest}

Cells were stained with anti-BrdU antibody, as well as PI, and analyzed by flow cytometry to analyze the influence of first and second generation mTOR inhibitors on cell cycle distribution. $\mathrm{PI}^{\text {low }}$ BrdU ${ }^{\text {low }}$ cells were assigned to $G_{1} / G_{0}$ phase, $\mathrm{PI}^{+} B r d U^{\text {high }}$ to $S$ and $\mathrm{PI}^{\text {high }} \mathrm{BrdU}^{\text {low }}$ to $\mathrm{G}_{2} / \mathrm{M}$ respectively. When compared to FM and DMSO control, cells that were treated with Everolimus or KU-0063794 showed a significant increase of $G_{1} / G_{0}$ phase and a significant decrease in $S$ phase with a 
higher magnitude for KU-0063794 (Figure 7a-c). While these effects were shown in a concentration dependent manner for KU-0063794, no statistically significant effects were found between the different concentrations of Everolimus. The number of cells in $\mathrm{G}_{2} / \mathrm{M}$ phase was not altered in any experimental group as compared to controls.

(a)

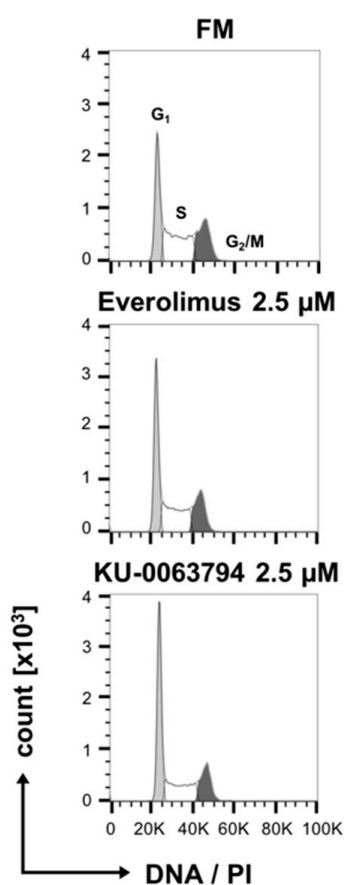

(b)
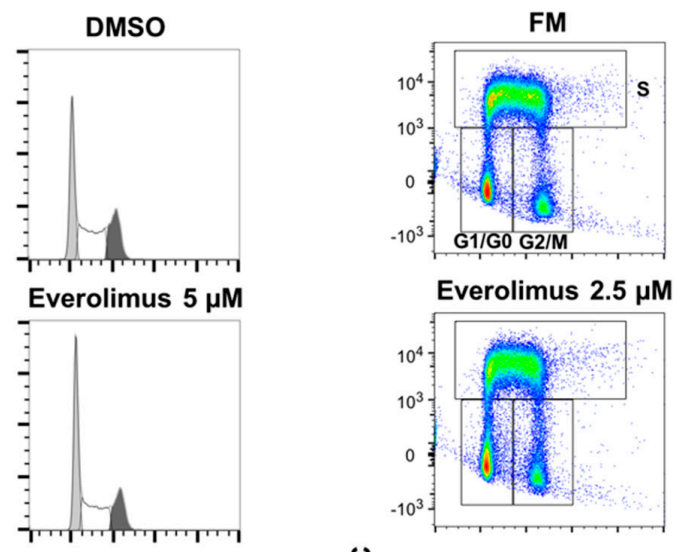

KU-0063794 $5 \mu \mathrm{M}$

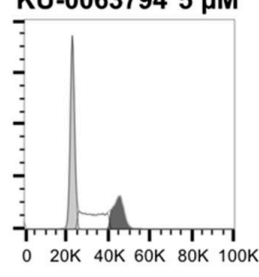

$020 \mathrm{~K} 40 \mathrm{~K} 60 \mathrm{~K} 80 \mathrm{~K} 100 \mathrm{~K}$

(c)

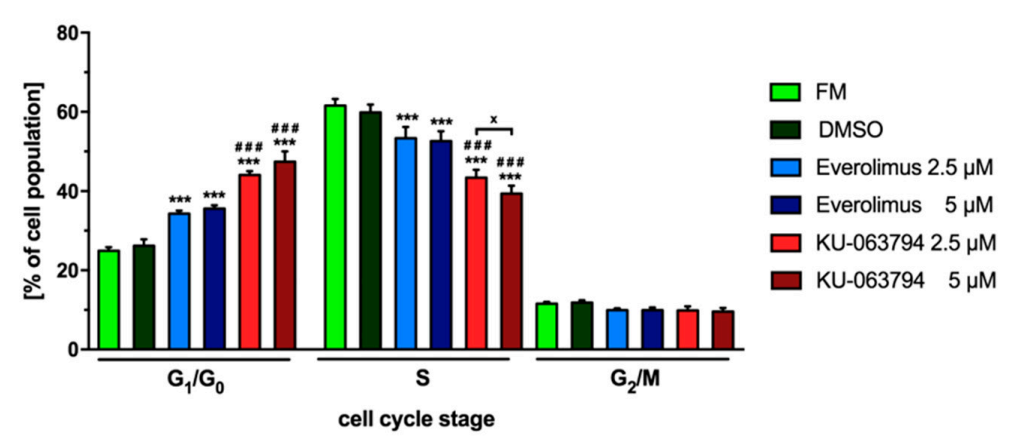

Figure 7. mTOR pathway inhibition drives N-HCC25 cells into $\mathrm{G}_{1} / \mathrm{G}_{0}$ cell cycle arrest. After an adherence phase of $24 \mathrm{~h}, \mathrm{~N}-\mathrm{HCC} 25$ cells were treated with Everolimus or KU-0063794 $(2.5 \mu \mathrm{M}$ or $5 \mu \mathrm{M}$ each) for $24 \mathrm{~h}$ and analyzed by flow cytometry for incorporation of BrdU and PI. The applied gating strategy is shown in supplemental Figure S3. Cells cultured in full medium (FM) with or without $0.05 \%$ DMSO served as controls. Representative data are shown in the form of histograms (a) and dot plots (b). Statistical analysis of cell cycle distribution obtained from (b) is shown in (c). Graphs represent mean $\pm \mathrm{SD} ; n(\mathrm{FM}, \mathrm{DMSO})=3, n$ (inhibitors) $=5$. Statistical significances are indicated as $* * * p<0.001$ vs. FM and DMSO control in the same cell cycle stage; \#\#\# $p<0.001$ vs. Everolimus $2.5 \mu \mathrm{M}$ and $5 \mu \mathrm{M}$ in same cell cycle stage; $x<0.05$, as indicated. (Two-way ANOVA with Tukey multiple comparison post hoc test, GraphPad Prism 7.0 software, La Jolla, CA, USA).

\section{Discussion}

NASH has become the major risk factor for HCC due to a worldwide increasing prevalence of obesity [12]. In the current study, a model specific NASH-HCC cell line was generated to investigate the biology of NASH-derived HCC [47]. This animal model resembled the human pathology in major metabolic (weight gain, insulin resistance, and glucose intolerance) and histopathological (steatosis, 
hepatocyte ballooning, inflammation, fibrosis) characteristics (Figure S1) [19]. The grade of NASH was determined by the widely used NAS and SAF Scores [48,49].

Cytogenetic analyses revealed numerical as well as structural aberrations in N-HCC25 cells that can be observed in HCC or cancer in general. Prominent chromosomal rearrangements were found besides the fundamental increase of ploidy grade, which is not necessarily unusual for hepatocytes, but might still be associated with gain-of-function. In this context, unbalanced translocation of chromosome 11 , deletion of chromosome 17, robertsonian fusion of chromosome 16 and 19, as well as the occurrence of double-minutes ( $\mathrm{r} / \mathrm{dmin} / \mathrm{cen})$ was of special interest. In silico analyses of affected genomic content revealed several genes that might be interesting in the context of HCC and other cancer entities. The investigation of potential gain-of-function of the genes located on amplified genomic content (tetrasomy, unbalanced translocation of chromosome 11) as well as loss-of-function of genes that are affected by deletion (chromosome 17) or spreading-of-inactivation by the unbalanced X-autosome translocation would be interesting. However, this would be too extensive for this study and will be addressed in our upcoming project. In tumor cells, the analysis of gene expression allows for conclusions regarding their origin and prognosis. Here, the expression of hepatocytic nuclear factor 4 (HNF4) in early passages indicated that N-HCC25 cells were derived from hepatocytes [50]. HNF4 is considered as protective factor due to its inhibiting effect on fibrosis and tumorigenesis of HCC by inhibition of $B$-catenin signalling [50,51]. External application of the transcription factor on HCC cell lines inhibited cell proliferation by differentiation of cancer cells to hepatocytes [9].

In the course of tumorigenesis, cancer cells undergo epithelial mesenchymal transition (EMT) [52], whereby epithelial markers are lost and mesenchymal features are gained [53]. The simultaneous expression of the EMT initiator CD44 [54] and the EMT markers Twist and Snail [55] indicate that EMT took place in N-HCC25. This process possibly resulted in the absence of the hepatocytic marker albumin and the loss of HNF4 in late passages.

In HCC, the loss of HNF4 [9,51,56] and expression of the cancer stem cell (CSC) markers CD44, CK19, Sox9, and EpCAM are considered to be indicators for poor prognosis [57-60]. In N-HCC25, these CSC markers were expressed in all passages. Previous studies characterized HCC with the expression of the cholangiocytic markers, such as CK19 and Sox9, as especially aggressive and, therefore, suggested defining a HCC with cholangiocellular differentiation [61,62]. EpCAM is considered to be a CSC marker, since its intracellular part EpICD mediates anchorage and growth factor independent cell proliferation, which is a typical trait in cancer [63]. It is crucial to assess the activity of the molecule rather than its presence, as the adhesion molecule is regularly expressed in the junctional zone of epithelial cells and upregulated in cancer cells. As only shown in the absence/presence of PCR, the activity of EpCAM in N-HCC25 was not assessed. In summary, the results of the gene expression analysis indicate that $\mathrm{N}-\mathrm{HCC} 25$ is a highly aggressive hepatocellular cancer cell line.

Recently, several findings have suggested that targeting tumor metabolism, which fundamentally differs from normal cells, might be a successful strategy for anticancer therapy [64]. For instance, cancer cells show little dependency on growth factors, but high dependency on energy supply $[65,66]$. In general, nutrient deficiency might cause $\mathrm{G}_{1} / \mathrm{G}_{0}$ arrest, if nutrients are required for multiplication, and might result in cell death, if nutrients are required for maintenance of $G_{1} / G_{0}$ phase [67]. In our study, the growth of N-HCC25 was significantly limited under treatment with halved amounts of FBS as compared to full medium, but did not lead to cell death. This indicates that N-HCC25 depended on FBS as a source for growth factors, despite the expression of EpCAM. This goes along with the finding of Zhou, Tang et al., who demonstrated that five human hepatoma cell lines showed restricted growth under FBS deprivation [68].

Tumor cells are also known for their excessive use of glucose via aerobic glycolysis (the so-called Warburg effect) [69]. Moreover, the expression of the glucose transporter GLUT1 increases during malignant transformation of hepatocytes and thus enables more energy supply and protein biosynthesis for mitosis [26]. In our study, the high dependency of N-HCC25 on glucose was confirmed. After an initial period of decelerated growth, glucose deprivation down to $50 \%$ resulted in cell death, 
as indicated by a sharp decrease of $\mathrm{CI}$, although glutamine was still available as energy supply. Interestingly, a slight increase of $\mathrm{CI}$ was observed $84 \mathrm{~h}$ after glucose deprivation. As the impedance that is given in CI cannot be equated with cell count, the increase either might have been induced by changes in cell morphology or reinstating cell growth. The latter may be enabled by survival of tumour initiating cells (TICs), which express more GLUT1 and 3 and can therefore survive glucose deprivation [25]. Taken together, our findings support the idea that limiting glucose supply might be a promising approach in anticancer therapy.

Glutamine serves as energy supply, enables DNA synthesis, reduces reactive oxygen species (ROS), and supports redox homeostasis [70]. Therefore, the deprivation of glutamine might inhibit cell growth [71] or lead to cell death. In N-HCC25 cells, the deprivation of glutamine to $50 \%$ only slightly affected cell proliferation in RTCA. The small effect in RTCA might have occurred because the still available amount of glutamine was a sufficient supply since treatment with glutamine-free medium for $48 \mathrm{~h}$ led to a significant decrease in cell growth. As restriction of glucose supply led to cell death, while glutamine restriction only slightly affected cell growth, it can be hypothesized that sufficient glucose supply ensured N-HCC25 survival, despite glutamine restriction. Furthermore, glutamine deprivation promotes a more efficient metabolism of glucose by oxidative phosphorylation instead of anaerobic glycolysis or biosynthetic pathways in order to enable cell survival [23]. Beyond that, two out of six HCC subgroups show a mutation in the $B$-catenin gene, leading to an overexpression of glutamine synthetase [22]. However, the mutation might either increase or attenuate glutamine dependency [24,72]. In HCV-HCC patients, glutamine inhibitors are applied to reduce fibrosis and inflammation, which both play an important role in pathophysiology of NASH [73]. Therefore, glutamine will remain an interesting target in NASH-HCC research.

As HCC is a heterogeneous tumor, various dysfunction of cellular processes and signalling pathways have been identified to be involved in the development of this cancer. These include alterations of telomerase reverse transcriptase (TERT), the Wnt pathway, JAK-STAT pathway, DNA repair mechanisms by TP53, chromatin remodelling by SWI/SNF, as well as the PI3K-AKT-mTOR pathway [74], all of which are investigated as possible targets for anticancer therapy. A clinically already addressed target is the mTOR pathway, which plays a major role in metabolism and cell growth. The upregulation of mTOR occurs in $40-50 \%$ of HCCs [27-29] and it is associated with low differentiation, poor prognosis, and early recurrence $[29,75,76]$. Despite preclinical success, so far limited clinical profit was achieved by the inhibition of mTOR. The first generation inhibitor Everolimus is known for its antineoplastic effects, which are mainly achieved due to the inhibition of proliferation and angiogenesis $[77,78]$. In several randomized controlled trials, survival benefits have been reported for solid cancers [79-81]. Regarding HCC, Everolimus is used in clinical studies for patients with advanced HCC, after liver transplantation and TACE [82-85]. Synergistic effects have been described for the application of Everolimus and calcineurin inhibitors to avoid HCC recurrence after liver transplantation [84,85] and for the combination of Everolimus with radiation [86]. However, low response rates have been reported in patients that were treated with single-agent Everolimus [79-81]. Additionally, preclinical studies did not show dose-dependent Everolimus' antitumor effects $[82,87,88]$. Our findings support this observation, as the deceleration in cell growth that was observed in RTCA was not dose-dependent for cells that were treated with Everolimus.

Cell cycle progression is promoted by mTORC1 [31]. Correspondingly, a decrease in cell cycle progression was found in N-HCC25 cells that were treated with Everolimus or the second generation inhibitor KU-0063794. Interestingly, the inhibiting effect of KU-0063794 was dose-dependent and it exceeded the effect of Everolimus, which suggests that KU-0063794 has a stronger effect on mTORC1 than Everolimus. This goes along with the finding of Garcia-Martinez that KU-0063794 leads to a greater dephosphorylation of the mTORC1 downstream target 4EBP1 than rapamycin [45]. The increased effect on mTORC1 might be a reason for the greater effects of KU-0063794 when compared to Everolimus. This circumstance is supported by the fact that mTORC2, also inhibited by KU-0063794, is considered to be responsible for cell survival [31]. 
Recently, investigators found out that autophagy, which is normally inhibited by mTORC1 [31], is upregulated in cells that were treated with single-agent Everolimus or KU-0063794 and promotes cell survival rather than cell death $[89,90]$. This is supported by the finding that cytotoxity in KU-0063794 treated cells is enhanced when autophagy is simultaneously inhibited [46]. Interestingly, Lee et al. described a synergistic cytotoxic effect of Everolimus and/or KU-0063794 by the inhibition of autophagy via a decrease of the positive autophagy regulator SIRT [89]. Taken together, mTOR remains an important target for research in HCC and especially the knockout of both complexes will play a role in future research.

In conclusion, N-HCC25 cells show characteristics of a highly proliferative NASH-derived hepatocellular carcinoma cell of robust malignancy and might, therefore, serve as a suitable in vitro model for future investigations of NASH-derived HCC.

\section{Materials and Methods}

All of the laboratory standard materials and chemicals were purchased from Merck (Darmstadt, Germany), Thermo Scientific (Waltham, MA, USA), VWR International (Darmstadt, Germany) and SERVA Electrophoresis GmbH (Heidelberg, Germany), if not otherwise stated.

\subsection{Animal Model}

We conducted the mouse model modified according to Yoshimoto, Loo et al., to induce hepatocellular carcinoma that is based on the development of a non-alcoholic steatohepatitis (NASH) [47]. Therefore, male C57BL/6 mice were treated with $50 \mu \mathrm{L} 0.5 \%$ DMBA (7,12-Dimethylbenz[a]anthracene) dissolved in acetone on the fourth or fifth postnatal day. With four weeks of age, these mice were fed western diet ( $40 \mathrm{kcal} \%$ fat, $20 \mathrm{kcal} \%$ fructose, and $2 \mathrm{kcal} \%$ cholesterol, Research Diets, Inc., New Brunswick, NJ, USA) for 30 weeks. With 34 weeks of age, in vivo $\mu \mathrm{CT}$ imaging was performed while using a gantry-based flat-panel microcomputed tomography scanner (TomoScope Duo, CT Imaging, Erlangen, Germany). The mice were scanned before and immediately after i.v. injection of Imeron ${ }^{\circledR} 400$ MCT (BRACCO Imaging, Konstanz, Germany, max. 60 $\mathrm{mg} / 25 \mathrm{~g}$ body weight into the tail vein), a non-ionic iodized radio-opaque substance. The animals were anesthetized by inhalation anesthesia in an anesthetic chamber (Drägerwerk AG, Lübeck, Germany, $2 \mathrm{Vol} \%$ isoflurane in $\mathrm{O}_{2}$ enriched air) during the entire in vivo imaging process. For each mouse, a CT scan was performed at $54 \mathrm{kV}(0.9 \mathrm{~mA})$, acquiring 1440 projections of size $1944 \times 1536$ over $9 \mathrm{~min}$. of continuous rotation or at $75 \mathrm{kV}(120 \mu \mathrm{A}), 2 \times 2$ detector binning, 1024 projections over 360 degrees, 1.3 times magnification of continuous rotation. A Feldkamp-type reconstruction algorithm (CT-Imaging, Erlangen, Germany) was implemented, including ring artifact correction. The reconstructed data were visualized and analyzed with Imalytics Preclinical software. Livers were segmented while using an automated segmentation method with interactive correction of segmentation errors. NASH was confirmed by the use of NAS and SAF Score. The animal experiments were approved by the governmental care and use committee (LANUV, Recklinghausen, NRW, Germany) and they were conducted in accordance with the federal German law and European directive 2010/63/EU on the protection of animals used for scientific procedures.

\subsection{Isolation of Primary Mouse Hepatocytes}

Isolation of N-HCC25 was conducted as described by Hesse, Jascke et al. [91].

\subsection{Cell Culture and Stimulation}

$\mathrm{N}-\mathrm{HCC} 25$ cells were cultured in Dulbecco's modified Eagle's (DMEM) containing $10 \%$ FBS, $4.5 \mathrm{~g} / \mathrm{L}$ D-glucose, $4 \mathrm{mM}$ glutamine, and $1 \%$ penicillin/streptomycin (full medium [FM]) at $37^{\circ} \mathrm{C}$ in a humidified $5 \% \mathrm{CO}_{2}$ atmosphere. All of the cell culture plastics used in subsequent experiments were coated with collagen A $(0.1 \mathrm{mg} / \mathrm{mL})$. The wash steps were conducted with PBS. Cells were detached by incubation with $2 \mathrm{~mL}$ trypsine/EDTA $\left(0.05 \% / 0.02 \%\right.$ in PBS, without $\left.\mathrm{Ca}^{2+} / \mathrm{Mg}^{2+}\right)$ for 
$20 \mathrm{~min}$. at $37^{\circ} \mathrm{C}$. Cells stained with $0.4 \%$ trypan blue were counted under light microscope (DM IL LED Fluo, Leica Microsystems CMS GmbH, Wetzlar, Germany) in a Neubauer chamber. Pictures of cell culture were taken with DFC345 FX from Leica. First generation (Everolimus) and second generation mTOR inhibitors (KU-0063794) dissolved in DMSO (Applichem, Darmstadt, Germany) were applied (Absource Diagnostics GmbH, Munich, Germany) to test the influence of mTOR on cell proliferation of N-HCC25 cells. Concentrations and incubation times are provided in the materials and methods section of each experiment. The control cells were cultured in full medium (FM control) or received DMSO as vehicle treatment (DMSO control).

\subsection{Cytogenetic Analysis}

Structural and numerical alterations of N-HCC25 cells $\left(2.5 \times 10^{4}\right)$ were explored by conventional karyotyping via GTG-banding. Metaphase spreads were obtained according to the standard protocols of hypotonic treatment $(0.56 \% \mathrm{KCl})$ and Carnoy's fixation (methanol/acetic acid, 3:1). GTG-banding was made by means of trypsin pretreatment for the partial removal of DNA-associated (chromosomal) proteins and subsequent Giemsa staining while using standard procedures. Microscopy was performed with Axioplan fluorescence microscope (Carl Zeiss, Jena, Germany) and IKARUS ${ }^{\mathrm{TM}}$ and ISIS ${ }^{\mathrm{TM}}$ digital imaging systems (MetaSystems, Altlussheim, Germany). 20 and 26 GTG banded metaphases were analysed per passage, respectively. Whole chromosome painting (wcp) probes for fluorescence in situ hybridisation (FISH)-based visualisation of $\mathrm{x}$ - and $\mathrm{y}$-chromosomes were purchased from Cytocell Ltd. (Cambridge, UK) and applied as recommended by the manufacturer.

\section{5. $P C R$}

Total RNA was isolated from $1 \times 10^{6} \mathrm{~N}-\mathrm{HCC} 25$ cells of diverse passages using peqGOLD RNAPure $^{\mathrm{TM}}$ (VWR Peqlab, Darmstadt, Germany), according to the manufacturer's recommendations. The concentration and purity of total RNA was measured with a Synergy HT reader (Biotek Instruments, Winooski, VT, USA). cDNA synthesis was carried out with $2 \mu \mathrm{g}$ total RNA. gDNA was digested by DNaseI treatment and cDNA was synthesized with Maxima RT while using oligo(dt)18 and random hexamer mixed priming. PCR was performed with $20 \mathrm{ng}$ cDNA in a Veriti ${ }^{\mathrm{TM}} 96-$-well Thermal Cycler with a standard PCR cycle protocol (Applied Biosystems, Darmstadt, Germany). Table 1 lists the information regarding primer sequence, annealing temperature, and amount of cycle per run. GAPDH served as reference gene. Gel electrophoresis was conducted while using $2 \%$ agarose gel containing $2 \mu \mathrm{L}$ Midori Green Advance (Biozym Scientific GmbH, Wien, Austria) at 140 Volt for $40 \mathrm{~min}$. (PowerPac Basic, Bio-rad Laboratories, Hercules, CA, USA). 100bp DNA ladder served as reference. Liver samples of DDC treated mice (DDC), a valuable model for stem cell activation in the liver, and untreated primary hepatocytes $(\mathrm{PH})$ were used as positive controls for marker expressions. No template control (NTC) served as the negative control.

\subsection{Western Blot}

$5 \times 10^{5} \mathrm{~N}-\mathrm{HCC} 25$ cells were seeded on cell culture dish $(100 \times 20 \mathrm{~mm})$ for 42 or $24 \mathrm{~h}$, respectively, in full medium prior to the treatments. Subsequently, the cells were stimulated for 6 or $24 \mathrm{~h}$ respectively with $2.5 \mu \mathrm{M}$ Everolimus or KU-0063794. In order to ensure mTOR activity, a confluence of $80 \%$ was not exceeded. After $48 \mathrm{~h}$ in total, proteins were isolated by sonification (6 cycles of $20 \mathrm{~s}$ with $10 \%$ power, Sonopuls, Bandelin, Berlin, Germany) in RIPA buffer. Lowry Assay (DC Protein Assay, Bio-Rad Laboratories, Hercules, CA, USA) determined the protein concentration, according to the manufacturer's recommendations while using the Synergy HT reader. Electrophoresis was conducted using precast gels (ServaGel TG Prime $4-12 \%$ ) at $50 \mathrm{~V}$ for $20 \mathrm{~min}$. and subsequently 120 Volt for $160 \mathrm{~min}$. Triple Color Standard III served as protein ladder. Immunoblot was carried out at $70 \mathrm{~V}$ for $135 \mathrm{~min}$. Blocking was conducted with milk or BSA for one hour at room temperature under continuous rocking. The primary antibodies were incubated at $4{ }^{\circ} \mathrm{C}$ over night and secondary antibodies for one hour at room temperature. Tables 3 and 4 shows all applied antibodies, including target size, order number, 
dilution, and required blocking solution. The membranes were incubated with Western Lightning Plus ECL (PerkinElmer Inc., MA, USA) for visualization. The scan was conducted with ChemoCam (ECL-Imager, Intas Science Imaging Instruments GmbH, Göttingen, Germany, program: Chemo Star). All of the wash steps were conducted with TBS-T. FM control and DMSO control (0.025\% DMSO for $24 \mathrm{~h}$ ) served as reference.

Table 3. List of primers for polymerase chain reaction (PCR).

\begin{tabular}{|c|c|c|c|c|}
\hline \multicolumn{2}{|c|}{ Primer } & \multirow{3}{*}{$\begin{array}{c}\text { Sequence } \\
\text { TCCTGGGCACGTTCTTGTAT } \\
\text { TGCTTTCTGGGTGTAGCGAA }\end{array}$} & \multirow{3}{*}{$\begin{array}{c}\begin{array}{c}\text { Annealing } \\
\text { Temperature }\end{array} \\
58.5^{\circ} \mathrm{C}\end{array}$} & \multirow{3}{*}{$\begin{array}{c}\text { Cycles } \\
30\end{array}$} \\
\hline \multirow{2}{*}{ Albumin } & for & & & \\
\hline & rev & & & \\
\hline \multirow{2}{*}{ HNF4 } & for & AAGGTGCCAACCTCAATTCATC & \multirow{2}{*}{$60^{\circ} \mathrm{C}$} & \multirow{2}{*}{30} \\
\hline & rev & CACATTGTCGGCTAAACCTGC & & \\
\hline \multirow{2}{*}{ CK19 } & for & GTCCTACAGATTGACAATG & \multirow{2}{*}{$57^{\circ} \mathrm{C}$} & \multirow{2}{*}{30} \\
\hline & rev & CACGCTCTGGATCTGTGACAG & & \\
\hline \multirow{2}{*}{ Sox9 } & for & GTGAAGAACGGACAAGCGGA & \multirow{2}{*}{$60^{\circ} \mathrm{C}$} & \multirow{2}{*}{40} \\
\hline & rev & GATTGCCCAGAGTGCTCGC & & \\
\hline \multirow{2}{*}{ EpCAM } & for & CGGCTCAGAGAGACTGTGTC & \multirow{2}{*}{$57.5^{\circ} \mathrm{C}$} & \multirow{2}{*}{30} \\
\hline & rev & GATCCAGTAGGTCCTCACGC & & \\
\hline \multirow{2}{*}{ CD44 } & for & CAGAGGCGACTAGATCCСТC & \multirow{2}{*}{$59^{\circ} \mathrm{C}$} & \multirow{2}{*}{30} \\
\hline & rev & GAGTCACAGTGCGGGAACTC & & \\
\hline \multirow{2}{*}{ Twist } & for & GCCGGAGACCTAGATGTCATTG & \multirow{2}{*}{$60{ }^{\circ} \mathrm{C}$} & \multirow{2}{*}{40} \\
\hline & rev & CCACGCCCTGATTCTTGTGA & & \\
\hline \multirow{2}{*}{ Snail } & for & TCTGCACGACCTGTGGAAAG & \multirow{2}{*}{$60^{\circ} \mathrm{C}$} & \multirow{2}{*}{40} \\
\hline & rev & GTTGGAGCGGTCAGCAAAAG & & \\
\hline \multirow{2}{*}{ GAPDH } & for & AGGTCGGTGTGAACGGATTTG & \multirow{2}{*}{$60^{\circ} \mathrm{C}$} & \multirow{2}{*}{40} \\
\hline & rev & TGTAGACCATGTAGTTGAGGTCA & & \\
\hline
\end{tabular}

Table 4. List of antibodies for Western blot.

\begin{tabular}{lcccc}
\hline \multicolumn{1}{c}{ Antibody } & Target Size & Order Number & Dilution & Blocking Solution \\
\hline mTOR & $289 \mathrm{kDa}$ & CST 2983 & $1: 500$ & milk powder \\
p-mTOR (Ser2481) & $289 \mathrm{kDa}$ & CST 2974 & $1: 1000$ & BSA \\
p-mTOR (Ser2448) & $289 \mathrm{kDa}$ & CST 5536 & $1: 500$ & BSA \\
Rictor & $200 \mathrm{kDa}$ & CST 2114 & $1: 2500$ & BSA \\
GßL & $37 \mathrm{kDa}$ & CST 3274 & $1: 1000$ & BSA \\
p-ribosomal & $32 \mathrm{kDa}$ & SC 293144 & $1: 200$ & BSA \\
protein S6 & $15-20 \mathrm{kDa}$ & CST 2855 & $1: 1000$ & BSA \\
p-4E-BP1 & $52 \mathrm{kDa}$ & PA5 16863 & $1: 1000$ & milk powder \\
B-Tubulin & - & CST 7076 & $1: 1000$ & - \\
Goat-anti-mouse & - & CST 7074 & $1: 2500$ & - \\
Goat-anti-rabbit & & & & \\
\hline
\end{tabular}

\subsection{Starvation Experiments}

$1 \times 10^{5} \mathrm{~N}-\mathrm{HCC} 25$ cells were seeded in six well culture plates in a total volume of $2 \mathrm{~mL}$ full medium. After $24 \mathrm{~h}$, basic nutrients were reduced for 24 or $48 \mathrm{~h}$. respectively, including the following concentrations: glutamine $(0,0.1,1$, or $2 \mathrm{mM})$, FBS $(0 \%, 1 \%, 2.5 \%$, or $5 \%)$, and glucose $(0,0.5,1$, or $2 \mathrm{~g} / \mathrm{L})$. Cells that were cultured in full medium served as control.

\subsection{RTCA (Real-Time Cell Analysis)}

$1 \times 10^{3}$ or $4 \times 10^{3} \mathrm{~N}-\mathrm{HCC} 25$ cells, respectively, were seeded in a collagen-coated 96-well E-plate of the xCELLigence system in $200 \mu \mathrm{L}$ full medium, according to the manufacturer's instructions under normal culture conditions (xCELLigence ${ }^{\circledR}$ RTCA SP instrument, Roche Diagnostics, Mannheim, Germany). After an adherence phase of $24 \mathrm{~h}, 100 \mu \mathrm{L}$ of the medium were exchanged. $48 \mathrm{~h}$ after seeding, the cells were either starved ( $5 \%$ FBS, $2 \mathrm{mM}$ glutamine, or $2.25 \mathrm{~g} / \mathrm{L}$ glucose) or treated with 
Everolimus or KU-0063794 (1, 2.5, or $5 \mu \mathrm{M})$. The impedance was measured by RTCA software version 1.2.1 at an interval of $15 \mathrm{~min}$. for $105 \mathrm{~h}$ and subsequently at an interval of one hour until the end of the experiment. The results are given as cell index $(\mathrm{CI})$ for time course depiction and endpoint analyses of pre-defined timepoints or as slope $(1 / \mathrm{h})$ for pre-defined growth phases. The data of nutrient reduction were normalized to the timepoint of stimulation. FM and DMSO control $(0.025 \%$ DMSO for $24 \mathrm{~h})$ served as reference.

\subsection{Flow Cytometry}

Two-dimensional cell cycle analysis was conducted to explore the effect of mTOR inhibition on cell cycle distribution by treatment with BrdU (5-bromo-2'-deoxyuridine, Applichem, Darmstadt, Germany) and PI (propidium iodide). While PI is incorporated in the entire DNA, the thymidine analogue BrdU is only contained in de novo synthesized DNA. Thus, the cells can be referred to different stages of cell cycle $\left(\mathrm{G}_{1} / \mathrm{G}_{0}\right.$ phase: $\mathrm{PI}^{\text {low }}$ BrdU ${ }^{\text {low }}, \mathrm{S}$ phase: $\mathrm{PI}^{+} \mathrm{BrdU} \mathrm{U}^{\text {high }} ; \mathrm{G}_{2} / \mathrm{M}$ phase: $\left.\mathrm{PI}^{\text {high }} \mathrm{BrdU}^{\mathrm{low}}\right)$. Initially, $1 \times 10^{6} \mathrm{~N}-\mathrm{HCC} 25$ cells were cultured in full medium for $24 \mathrm{~h}$ and subsequently incubated with Everolimus or KU-0063794 $(2.5 \mu \mathrm{M}$ or $5 \mu \mathrm{M})$ for $24 \mathrm{~h}$. After pulse-labeling with $10 \mu \mathrm{M}$ BrdU for $30 \mathrm{~min}$. at $37^{\circ} \mathrm{C}$, the cells were immediately harvested for BrdU/PI staining. First, the cells were fixated with $70 \%$ ethanol at $-20^{\circ} \mathrm{C}$ and incubated with $2 \mathrm{~N} \mathrm{HCl}$ (Applichem, Darmstadt, Germany) containing $0.5 \%$ Triton X-100 at room temperature for $30 \mathrm{~min}$. each. After neutralising with $0.1 \mathrm{M} \mathrm{Na}_{2} \mathrm{~B}_{4} \mathrm{O}_{7}$ at $\mathrm{pH}$ 8.5, cell count was adjusted to 1 million/mL in PBS with $1 \%$ BSA and $0.05 \%$ Tween-20. After incubation with anti-BrdU antibody (mouse, clone Bu20a, Agilent, Santa Clara, CA, USA; 1:100 in PBS with 1\% BSA) at $4{ }^{\circ} \mathrm{C}$ overnight, an Alexa Fluor 488-conjugated secondary antibody (Goat anti-mouse IgG; 1:200 in PBS with 1\% BSA) was added for $30 \mathrm{~min}$. at room temperature, being protected from light. Finally, the cells were stained with PI (10 $\mu \mathrm{g} / \mathrm{mL}$ in PBS). Each step was followed by a wash step with PBS with $1 \%$ BSA. FM and DMSO control (0.05\% DMSO) served as reference. Samples were quantified with a BD LSRFortessa Cell Analyzer (BD Biosiences, San Jose, CA, USA). FlowJo Software Version 10 (FlowJo LLC, Ashland, Oregon, USA) was used for data analysis. The applied gating strategy and technical controls are provided in the supplements (Figure S3).

\subsection{Statistical Analysis}

The Bartlett test was used to check for variance homogeneity. Normal distribution was tested with the Shapiro-Wilk test. Multiple comparisons were analyzed by one- or two-way ANOVA followed by Bonferroni's or Tukey's multiple comparison post-hoc tests, as indicated in the figure legends. Data represent mean \pm SEM if not otherwise stated. All statistical analyses and graphs were created with GraphPad Prism 7.0 (GraphPad; La Jolla, USA) and JMP 10.0 Software (SAS Institute Inc., NC, USA). $p$ values $<0.05$ were considered as statistically significant.

Supplementary Materials: Supplementary materials can be found at http://www.mdpi.com/1422-0067/20/22/ 5658/s1.

Author Contributions: A.K. and A.F. designed the study. A.K., J.W., H.S., J.N., R.E. and A.F. conducted the experiments. A.K., J.W., H.S., J.N., D.H. and A.F. performed data collection. A.K., J.W., H.S., J.N., T.C. and A.F. conducted data analysis. T.C., U.P.N. and T.F.U. made substantial contributions to the interpretation of the data and relevance. J.W., A.F. and A.K. drafted the manuscript. A.K., J.W., H.S., J.N., U.P.N., T.C., T.F.U. and A.F. revised the manuscript content. All authors read and approved the final manuscript.

Funding: This research received no external funding.

Acknowledgments: We want to thank Walter Becker (Department of Pharmacology and Toxicology, Uniklinik RWTH Aachen, Germany) for providing us the xCELLigence system and appropriate material. We thank Nina Koch, Nelli Neuberger, and Ilka Sauer for their excellent technical assistance.

Conflicts of Interest: The authors declare no conflict of interest. 


\section{Abbreviation}

\begin{tabular}{|c|c|}
\hline AKT & protein kinase B \\
\hline BSA & bovine serum albumin \\
\hline CI & cell index \\
\hline CSCs & cancer stem cells \\
\hline DDC & liver samples from DDC (diethyl1,4-dihydro-2,4,6-trimethyl- \\
\hline & 3,5-pyridinedicarboxylate) treated mice \\
\hline DMBA & 7,12-Dimethylbenz[a]anthracene \\
\hline DMEM & Dulbecco's modified Eagle's medium \\
\hline DMSO & dimethyl-sulfoxide \\
\hline EMT & epithelial-mesenchymal transition \\
\hline EpCAM & Epithelial cell adhesion molecule \\
\hline EpICD & intracellular domain of EpCAM \\
\hline FBS & fetal bovine serum \\
\hline FISH & fluorescence in situ hybridization \\
\hline FM & full medium control \\
\hline $\mathrm{G}_{1} / \mathrm{G}_{0}$ & $\mathrm{G}_{1} / \mathrm{G}_{0}$-phase of cell cycle \\
\hline $\mathrm{G}_{2} / \mathrm{M}$ & $\mathrm{G}_{2} / \mathrm{M}$ - phase of cell cycle \\
\hline GAPDH & glycerinaldehyde- 3- phosphate- dehydrogenase \\
\hline gDNA & genomic DNA \\
\hline GLUT1 & glucose transporter 1 \\
\hline GßL & G protein $\beta$-subunit-like protein, also known as mLST8 \\
\hline HBV & hepatitis B virus \\
\hline Hc & pericentric heterochromatin \\
\hline HCC & Hepatocellular cancer \\
\hline $\mathrm{HCV}$ & hepatitis $C$ virus \\
\hline HNF4 & hepatocyte nuclear factor 4 \\
\hline HRP & horseradish peroxidase \\
\hline LST8 & mammalian lethal with SEC13 protein 8 \\
\hline mTOR & mechanistic (previously: mammalian) target of rapamycin \\
\hline mTORC1 & mTOR complex 1 \\
\hline mTORC2 & mTOR complex 2 \\
\hline N-HCC25 & newly established cell line isolated from murine NASH-HCC model \\
\hline NAFLD & non-alcoholic fatty liver disease \\
\hline NASH & non-alcoholic steatohepatitis \\
\hline NTC & No template control \\
\hline p-4E-BP1 & phosphorylated eukaryotic translation initiation factor $4 \mathrm{E}$ binding protein 1 \\
\hline p-mTOR (Ser2448) & phospho-mTOR (Serin 2448) \\
\hline p-mTOR (Ser2481) & phospho-mTOR (Serin 2481) \\
\hline p-rp S6 & phospho-ribosomal protein S6 \\
\hline P4 & passage of cells number 4 \\
\hline PBS & phosphate buffered saline \\
\hline PCR & polymerase chain reaction \\
\hline $\mathrm{PH}$ & primary hepatocytes \\
\hline PI & propidium iodide \\
\hline PI3K & Phophoinositide-3-kinase \\
\hline $\mathrm{Rb}$ & Robertsonian Fusion \\
\hline Rictor & rapamycin insensitive companion of mTOR \\
\hline RIPA & Radioimmunoprecipitation assay buffer \\
\hline RNA & ribonucleic acid \\
\hline
\end{tabular}




$\begin{array}{ll}\text { RTCA } & \text { real-time cell analyser } \\ \text { S } & \text { S-phase of cell cycle } \\ \text { SD } & \text { standard deviation } \\ \text { SEM } & \text { standard error of the mean } \\ \text { SIRT } & \text { sirtuin } \\ \text { Snail } & \text { snail familiy zinc finger 1 } \\ \text { Sox9 } & \text { SRY (sex determing region) -box 9 } \\ \text { T } & \text { unbalanced translocation } \\ t_{1-3} & \text { timepoint } \\ \text { TACE } & \text { transarterial chemoembolization } \\ \text { TBS-T } & \text { tween supplemented tris-buffered saline } \\ \text { TICs } & \text { tumour initiating cells } \\ \text { Twist } & \text { twist basic helix-loop-helix transcription factor 1 } \\ \text { wcp } & \text { whole-chromosome-painting } \\ \mu C T & \text { micro comupter-tomography }\end{array}$

\section{References}

1. Lamarca, A.; Mendiola, M.; Barriuso, J. Hepatocellular carcinoma: Exploring the impact of ethnicity on molecular biology. Crit. Rev. Oncol. Hematol. 2016, 105, 65-72. [CrossRef] [PubMed]

2. Forner, A.; Reig, M.E.; de Lope, C.R.; Bruix, J. Current strategy for staging and treatment: The BCLC update and future prospects. Semin. Liver Dis. 2010, 30, 61-74. [CrossRef] [PubMed]

3. Llovet, J.M.; Ricci, S.; Mazzaferro, V.; Hilgard, P.; Gane, E.; Blanc, J.F.; de Oliveira, A.C.; Santoro, A.; Raoul, J.L.; Forner, A.; et al. Sorafenib in advanced hepatocellular carcinoma. N. Engl. J. Med. 2008, 359, 378-390. [CrossRef] [PubMed]

4. Bruix, J.; Qin, S.; Merle, P.; Granito, A.; Huang, Y.H.; Bodoky, G.; Pracht, M.; Yokosuka, O.; Rosmorduc, O.; Breder, V.; et al. Regorafenib for patients with hepatocellular carcinoma who progressed on sorafenib treatment (RESORCE): A randomised, double-blind, placebo-controlled, phase 3 trial. Lancet 2017, 389, 56-66. [CrossRef]

5. Imamura, H.; Matsuyama, Y.; Tanaka, E.; Ohkubo, T.; Hasegawa, K.; Miyagawa, S.; Sugawara, Y.; Minagawa, M.; Takayama, T.; Kawasaki, S.; et al. Risk factors contributing to early and late phase intrahepatic recurrence of hepatocellular carcinoma after hepatectomy. J. Hepatol. 2003, 38, 200-207. [CrossRef]

6. Forner, A.; Llovet, J.M.; Bruix, J. Hepatocellular carcinoma. Lancet 2012, 379, 1245-1255. [CrossRef]

7. Bruix, J.; Gores, G.J.; Mazzaferro, V. Hepatocellular carcinoma: Clinical frontiers and perspectives. Gut 2014, 63, 844-855. [CrossRef] [PubMed]

8. Colvin, H.; Mizushima, T.; Eguchi, H.; Takiguchi, S.; Doki, Y.; Mori, M. Gastroenterological surgery in Japan: The past, the present and the future. Ann. Gastroenterol. Surg. 2017, 1, 5-10. [CrossRef] [PubMed]

9. Yin, C.; Lin, Y.; Zhang, X.; Chen, Y.X.; Zeng, X.; Yue, H.Y.; Hou, J.L.; Deng, X.; Zhang, J.P.; Han, Z.G.; et al. Differentiation therapy of hepatocellular carcinoma in mice with recombinant adenovirus carrying hepatocyte nuclear factor-4alpha gene. Hepatology 2008, 48, 1528-1539. [CrossRef] [PubMed]

10. Araujo, A.R.; Rosso, N.; Bedogni, G.; Tiribelli, C.; Bellentani, S. Global epidemiology of non-alcoholic fatty liver disease/non-alcoholic steatohepatitis: What we need in the future. Liver Int. Off. J. Int. Assoc. Study Liver 2018, 38 (Suppl. 1), 47-51. [CrossRef]

11. Puchades Renau, L.; Berenguer, M. Introduction to hepatitis C virus infection: Overview and history of hepatitis C virus therapies. Hemodial. Int. 2018, 22 (Suppl. 1), S8-S21. [CrossRef]

12. Sun, D.; Zhu, L.; Yao, D.; Chen, L.; Fu, L.; Ouyang, L. Recent progress in potential anti-hepatitis B virus agents: Structural and pharmacological perspectives. Eur. J. Med. Chem. 2018, 147, 205-217. [CrossRef] [PubMed]

13. Bataller, R.; Paik, Y.H.; Lindquist, J.N.; Lemasters, J.J.; Brenner, D.A. Hepatitis C virus core and nonstructural proteins induce fibrogenic effects in hepatic stellate cells. Gastroenterology 2004, 126, 529-540. [CrossRef] [PubMed]

14. Schuppan, D.; Krebs, A.; Bauer, M.; Hahn, E.G. Hepatitis C and liver fibrosis. Cell Death Differ. 2003, 10 (Suppl. 1), S59-S67. [CrossRef] 
15. Angulo, P. Nonalcoholic fatty liver disease. N. Engl. J. Med. 2002, 346, 1221-1231. [CrossRef] [PubMed]

16. Jou, J.; Choi, S.S.; Diehl, A.M. Mechanisms of disease progression in nonalcoholic fatty liver disease. Semin. Liver Dis. 2008, 28, 370-379. [CrossRef] [PubMed]

17. Ascha, M.S.; Hanouneh, I.A.; Lopez, R.; Tamimi, T.A.; Feldstein, A.F.; Zein, N.N. The incidence and risk factors of hepatocellular carcinoma in patients with nonalcoholic steatohepatitis. Hepatology 2010, 51, 1972-1978. [CrossRef] [PubMed]

18. Adams, L.A.; Lymp, J.F.; St Sauver, J.; Sanderson, S.O.; Lindor, K.D.; Feldstein, A.; Angulo, P. The natural history of nonalcoholic fatty liver disease: A population-based cohort study. Gastroenterology 2005, 129, 113-121. [CrossRef] [PubMed]

19. Maher, J.J.; Leon, P.; Ryan, J.C. Beyond insulin resistance: Innate immunity in nonalcoholic steatohepatitis. Hepatology 2008, 48, 670-678. [CrossRef] [PubMed]

20. Mummadi, R.R.; Kasturi, K.S.; Chennareddygari, S.; Sood, G.K. Effect of bariatric surgery on nonalcoholic fatty liver disease: Systematic review and meta-analysis. Clin. Gastroenterol. Hepatol. 2008, 6, 1396-1402. [CrossRef] [PubMed]

21. Oseini, A.M.; Sanyal, A.J. Therapies in non-alcoholic steatohepatitis (NASH). Liver Int. 2017, 37 (Suppl. 1), 97-103. [CrossRef] [PubMed]

22. Boyault, S.; Rickman, D.S.; de Reynies, A.; Balabaud, C.; Rebouissou, S.; Jeannot, E.; Herault, A.; Saric, J.; Belghiti, J.; Franco, D.; et al. Transcriptome classification of HCC is related to gene alterations and to new therapeutic targets. Hepatology 2007, 45, 42-52. [CrossRef] [PubMed]

23. Byun, J.K.; Choi, Y.K.; Kang, Y.N.; Jang, B.K.; Kang, K.J.; Jeon, Y.H.; Lee, H.W.; Jeon, J.H.; Koo, S.H.; Jeong, W.I.; et al. Retinoic acid-related orphan receptor alpha reprograms glucose metabolism in glutamine-deficient hepatoma cells. Hepatology 2015, 61, 953-964. [CrossRef] [PubMed]

24. Chiu, M.; Tardito, S.; Pillozzi, S.; Arcangeli, A.; Armento, A.; Uggeri, J.; Missale, G.; Bianchi, M.G.; Barilli, A.; Dall'Asta, V.; et al. Glutamine depletion by crisantaspase hinders the growth of human hepatocellular carcinoma xenografts. Br. J. Cancer 2014, 111, 1159-1167. [CrossRef] [PubMed]

25. Zhang, H.L.; Wang, M.D.; Zhou, X.; Qin, C.J.; Fu, G.B.; Tang, L.; Wu, H.; Huang, S.; Zhao, L.H.; Zeng, M.; et al. Blocking preferential glucose uptake sensitizes liver tumor-initiating cells to glucose restriction and sorafenib treatment. Cancer Lett. 2017, 388, 1-11. [CrossRef] [PubMed]

26. Amann, T.; Hellerbrand, C. GLUT1 as a therapeutic target in hepatocellular carcinoma. Expert Opin. Ther. Targets 2009, 13, 1411-1427. [CrossRef] [PubMed]

27. Sahin, F.; Kannangai, R.; Adegbola, O.; Wang, J.; Su, G.; Torbenson, M. mTOR and P70 S6 kinase expression in primary liver neoplasms. Clin. Cancer Res. 2004, 10, 8421-8425. [CrossRef] [PubMed]

28. Sieghart, W.; Fuereder, T.; Schmid, K.; Cejka, D.; Werzowa, J.; Wrba, F.; Wang, X.; Gruber, D.; Rasoul-Rockenschaub, S.; Peck-Radosavljevic, M.; et al. Mammalian target of rapamycin pathway activity in hepatocellular carcinomas of patients undergoing liver transplantation. Transplantation 2007, 83, 425-432. [CrossRef] [PubMed]

29. Villanueva, A.; Chiang, D.Y.; Newell, P.; Peix, J.; Thung, S.; Alsinet, C.; Tovar, V.; Roayaie, S.; Minguez, B.; Sole, M.; et al. Pivotal role of mTOR signaling in hepatocellular carcinoma. Gastroenterology 2008, 135, 1972-1983. [CrossRef] [PubMed]

30. Schulze, K.; Imbeaud, S.; Letouze, E.; Alexandrov, L.B.; Calderaro, J.; Rebouissou, S.; Couchy, G.; Meiller, C.; Shinde, J.; Soysouvanh, F.; et al. Exome sequencing of hepatocellular carcinomas identifies new mutational signatures and potential therapeutic targets. Nat. Genet. 2015, 47, 505-511. [CrossRef] [PubMed]

31. Laplante, M.; Sabatini, D.M. mTOR signaling in growth control and disease. Cell 2012, 149, $274-293$. [CrossRef] [PubMed]

32. Garcia-Martinez, J.M.; Alessi, D.R. mTOR complex 2 (mTORC2) controls hydrophobic motif phosphorylation and activation of serum- and glucocorticoid-induced protein kinase 1 (SGK1). Biochem. J. 2008, 416, 375-385. [CrossRef] [PubMed]

33. Sarbassov, D.D.; Guertin, D.A.; Ali, S.M.; Sabatini, D.M. Phosphorylation and regulation of Akt/PKB by the rictor-mTOR complex. Science 2005, 307, 1098-1101. [CrossRef] [PubMed]

34. Sarbassov, D.D.; Ali, S.M.; Kim, D.H.; Guertin, D.A.; Latek, R.R.; Erdjument-Bromage, H.; Tempst, P.; Sabatini, D.M. Rictor, a novel binding partner of $\mathrm{mTOR}$, defines a rapamycin-insensitive and raptorindependent pathway that regulates the cytoskeleton. Curr. Biol. 2004, 14, 1296-1302. [CrossRef] [PubMed] 
35. Jacinto, E.; Loewith, R.; Schmidt, A.; Lin, S.; Ruegg, M.A.; Hall, A.; Hall, M.N. Mammalian TOR complex 2 controls the actin cytoskeleton and is rapamycin insensitive. Nat. Cell Biol. 2004, 6, 1122-1128. [CrossRef] [PubMed]

36. Neuhaus, P.; Klupp, J.; Langrehr, J.M. mTOR inhibitors: An overview. Liver Transpl. 2001, 7, $473-484$. [CrossRef] [PubMed]

37. Chapman, T.M.; Perry, C.M. Everolimus. Drugs 2004, 64, 861-872. [CrossRef] [PubMed]

38. Matter, M.S.; Decaens, T.; Andersen, J.B.; Thorgeirsson, S.S. Targeting the mTOR pathway in hepatocellular carcinoma: Current state and future trends. J. Hepatol. 2014, 60, 855-865. [CrossRef] [PubMed]

39. Zhu, A.X.; Kudo, M.; Assenat, E.; Cattan, S.; Kang, Y.K.; Lim, H.Y.; Poon, R.T.; Blanc, J.F.; Vogel, A.; Chen, C.L.; et al. Effect of everolimus on survival in advanced hepatocellular carcinoma after failure of sorafenib: The EVOLVE-1 randomized clinical trial. JAMA 2014, 312, 57-67. [CrossRef] [PubMed]

40. Evert, M.; Calvisi, D.F.; Evert, K.; De Murtas, V.; Gasparetti, G.; Mattu, S.; Destefanis, G.; Ladu, S.; Zimmermann, A.; Delogu, S.; et al. V-AKT murine thymoma viral oncogene homolog/mammalian target of rapamycin activation induces a module of metabolic changes contributing to growth in insulin-induced hepatocarcinogenesis. Hepatology 2012, 55, 1473-1484. [CrossRef] [PubMed]

41. Grabinski, N.; Ewald, F.; Hofmann, B.T.; Staufer, K.; Schumacher, U.; Nashan, B.; Jucker, M. Combined targeting of AKT and mTOR synergistically inhibits proliferation of hepatocellular carcinoma cells. Mol. Cancer 2012, 11, 85. [CrossRef] [PubMed]

42. Kirstein, M.M.; Boukouris, A.E.; Pothiraju, D.; Buitrago-Molina, L.E.; Marhenke, S.; Schutt, J.; Orlik, J.; Kuhnel, F.; Hegermann, J.; Manns, M.P.; et al. Activity of the mTOR inhibitor RAD001, the dual mTOR and PI3-kinase inhibitor BEZ235 and the PI3-kinase inhibitor BKM120 in hepatocellular carcinoma. Liver Int. 2013, 33, 780-793. [CrossRef] [PubMed]

43. Masuda, M.; Shimomura, M.; Kobayashi, K.; Kojima, S.; Nakatsura, T. Growth inhibition by NVP-BEZ235, a dual PI3K/mTOR inhibitor, in hepatocellular carcinoma cell lines. Oncol. Rep. 2011, 26, 1273-1279. [CrossRef] [PubMed]

44. Thomas, H.E.; Mercer, C.A.; Carnevalli, L.S.; Park, J.; Andersen, J.B.; Conner, E.A.; Tanaka, K.; Matsutani, T.; Iwanami, A.; Aronow, B.J.; et al. mTOR inhibitors synergize on regression, reversal of gene expression, and autophagy in hepatocellular carcinoma. Sci. Transl. Med. 2012, 4, 139ra184. [CrossRef] [PubMed]

45. Garcia-Martinez, J.M.; Moran, J.; Clarke, R.G.; Gray, A.; Cosulich, S.C.; Chresta, C.M.; Alessi, D.R. Ku-0063794 is a specific inhibitor of the mammalian target of rapamycin (mTOR). Biochem. J. 2009, 421, 29-42. [CrossRef] [PubMed]

46. Yongxi, T.; Haijun, H.; Jiaping, Z.; Guoliang, S.; Hongying, P. Autophagy inhibition sensitizes KU-0063794-mediated anti-HepG2 hepatocellular carcinoma cell activity in vitro and in vivo. Biochem. Biophys. Res. Commun. 2015, 465, 494-500. [CrossRef] [PubMed]

47. Yoshimoto, S.; Loo, T.M.; Atarashi, K.; Kanda, H.; Sato, S.; Oyadomari, S.; Iwakura, Y.; Oshima, K.; Morita, H.; Hattori, M.; et al. Obesity-induced gut microbial metabolite promotes liver cancer through senescence secretome. Nature 2013, 499, 97-101. [CrossRef] [PubMed]

48. Kleiner, D.E.; Brunt, E.M.; Van Natta, M.; Behling, C.; Contos, M.J.; Cummings, O.W.; Ferrell, L.D.; Liu, Y.C.; Torbenson, M.S.; Unalp-Arida, A.; et al. Design and validation of a histological scoring system for nonalcoholic fatty liver disease. Hepatology 2005, 41, 1313-1321. [CrossRef] [PubMed]

49. Bedossa, P.; Poitou, C.; Veyrie, N.; Bouillot, J.L.; Basdevant, A.; Paradis, V.; Tordjman, J.; Clement, K. Histopathological algorithm and scoring system for evaluation of liver lesions in morbidly obese patients. Hepatology 2012, 56, 1751-1759. [CrossRef] [PubMed]

50. Kuo, C.J.; Conley, P.B.; Chen, L.; Sladek, F.M.; Darnell, J.E., Jr.; Crabtree, G.R. A transcriptional hierarchy involved in mammalian cell-type specification. Nature 1992, 355, 457-461. [CrossRef] [PubMed]

51. Ning, B.F.; Ding, J.; Yin, C.; Zhong, W.; Wu, K.; Zeng, X.; Yang, W.; Chen, Y.X.; Zhang, J.P.; Zhang, X.; et al. Hepatocyte nuclear factor 4 alpha suppresses the development of hepatocellular carcinoma. Cancer Res. 2010, 70, 7640-7651. [CrossRef] [PubMed]

52. Ding, W.; You, H.; Dang, H.; LeBlanc, F.; Galicia, V.; Lu, S.C.; Stiles, B.; Rountree, C.B. Epithelial-tomesenchymal transition of murine liver tumor cells promotes invasion. Hepatology 2010, 52, 945-953. [CrossRef] [PubMed]

53. Kalluri, R.; Weinberg, R.A. The basics of epithelial-mesenchymal transition. J. Clin. Investig. 2009, 119, 1420-1428. [CrossRef] [PubMed] 
54. Yoshihara, S.; Kon, A.; Kudo, D.; Nakazawa, H.; Kakizaki, I.; Sasaki, M.; Endo, M.; Takagaki, K. A hyaluronan synthase suppressor, 4-methylumbelliferone, inhibits liver metastasis of melanoma cells. FEBS Lett. 2005, 579, 2722-2726. [CrossRef] [PubMed]

55. Zeisberg, M.; Neilson, E.G. Biomarkers for epithelial-mesenchymal transitions. J. Clin. Investig. 2009, 119, 1429-1437. [CrossRef] [PubMed]

56. Walesky, C.; Edwards, G.; Borude, P.; Gunewardena, S.; O’Neil, M.; Yoo, B.; Apte, U. Hepatocyte nuclear factor 4 alpha deletion promotes diethylnitrosamine-induced hepatocellular carcinoma in rodents. Hepatology 2013, 57, 2480-2490. [CrossRef] [PubMed]

57. Kim, H.; Choi, G.H.; Na, D.C.; Ahn, E.Y.; Kim, G.I.; Lee, J.E.; Cho, J.Y.; Yoo, J.E.; Choi, J.S.; Park, Y.N. Human hepatocellular carcinomas with "Stemness"-related marker expression: Keratin 19 expression and a poor prognosis. Hepatology 2011, 54, 1707-1717. [CrossRef] [PubMed]

58. Guo, X.; Xiong, L.; Sun, T.; Peng, R.; Zou, L.; Zhu, H.; Zhang, J.; Li, H.; Zhao, J. Expression features of SOX9 associate with tumor progression and poor prognosis of hepatocellular carcinoma. Diagn. Pathol. 2012, 7, 44. [CrossRef] [PubMed]

59. Mima, K.; Okabe, H.; Ishimoto, T.; Hayashi, H.; Nakagawa, S.; Kuroki, H.; Watanabe, M.; Beppu, T.; Tamada, M.; Nagano, O.; et al. CD44s regulates the TGF-beta-mediated mesenchymal phenotype and is associated with poor prognosis in patients with hepatocellular carcinoma. Cancer Res. 2012, 72, 3414-3423. [CrossRef] [PubMed]

60. Ko, C.J.; Li, C.J.; Wu, M.Y.; Chu, P.Y. Overexpression of epithelial cell adhesion molecule as a predictor of poor outcome in patients with hepatocellular carcinoma. Exp. Ther. Med. 2018, 16, 4810-4816. [CrossRef] [PubMed]

61. Uenishi, T.; Kubo, S.; Yamamoto, T.; Shuto, T.; Ogawa, M.; Tanaka, H.; Tanaka, S.; Kaneda, K.; Hirohashi, K. Cytokeratin 19 expression in hepatocellular carcinoma predicts early postoperative recurrence. Cancer Sci. 2003, 94, 851-857. [CrossRef] [PubMed]

62. Lu, X.Y.; Xi, T.; Lau, W.Y.; Dong, H.; Zhu, Z.; Shen, F.; Wu, M.C.; Cong, W.M. Hepatocellular carcinoma expressing cholangiocyte phenotype is a novel subtype with highly aggressive behavior. Ann. Surg. Oncol. 2011, 18, 2210-2217. [CrossRef] [PubMed]

63. Munz, M.; Baeuerle, P.A.; Gires, O. The emerging role of EpCAM in cancer and stem cell signaling. Cancer Res. 2009, 69, 5627-5629. [CrossRef] [PubMed]

64. Vander Heiden, M.G. Targeting cancer metabolism: A therapeutic window opens. Nat. Rev. Drug Discov. 2011, 10, 671-684. [CrossRef] [PubMed]

65. Zhao, Y.; Butler, E.B.; Tan, M. Targeting cellular metabolism to improve cancer therapeutics. Cell Death Dis. 2013, 4, e532. [CrossRef] [PubMed]

66. DeBerardinis, R.J.; Mancuso, A.; Daikhin, E.; Nissim, I.; Yudkoff, M.; Wehrli, S.; Thompson, C.B. Beyond aerobic glycolysis: Transformed cells can engage in glutamine metabolism that exceeds the requirement for protein and nucleotide synthesis. Proc. Natl. Acad. Sci. USA 2007, 104, 19345-19350. [CrossRef] [PubMed]

67. Bettger, W.J.; McKeehan, W.L. Mechanisms of cellular nutrition. Physiol. Rev. 1986, 66, 1-35. [CrossRef] [PubMed]

68. Zhou, J.; Tang, Y.; Xie, Z.J.; Lu, J.N.; Deng, J.H.; Huang, X.W.; Chuan Hooi, S.; He, M.; Lu, G.D. AKT activation was not essential for hepatocellular carcinoma cell survival under glucose deprivation. Anti-Cancer Drugs 2017, 28, 427-435. [CrossRef] [PubMed]

69. Kim, J.W.; Dang, C.V. Cancer's molecular sweet tooth and the Warburg effect. Cancer Res. 2006, 66, 8927-8930. [CrossRef] [PubMed]

70. DeBerardinis, R.J.; Cheng, T. Q's next: The diverse functions of glutamine in metabolism, cell biology and cancer. Oncogene 2010, 29, 313-324. [CrossRef] [PubMed]

71. Qing, G.; Li, B.; Vu, A.; Skuli, N.; Walton, Z.E.; Liu, X.; Mayes, P.A.; Wise, D.R.; Thompson, C.B.; Maris, J.M.; et al. ATF4 regulates MYC-mediated neuroblastoma cell death upon glutamine deprivation. Cancer Cell 2012, 22, 631-644. [CrossRef] [PubMed]

72. Tardito, S.; Chiu, M.; Uggeri, J.; Zerbini, A.; Da Ros, F.; Dall'Asta, V.; Missale, G.; Bussolati, O. L-Asparaginase and inhibitors of glutamine synthetase disclose glutamine addiction of beta-catenin-mutated human hepatocellular carcinoma cells. Curr. Cancer Drug Targets 2011, 11, 929-943. [PubMed] 
73. Levy, P.L.; Duponchel, S.; Eischeid, H.; Molle, J.; Michelet, M.; Diserens, G.; Vermathen, M.; Vermathen, P.; Dufour, J.F.; Dienes, H.P.; et al. Hepatitis C virus infection triggers a tumor-like glutamine metabolism. Hepatology 2017, 65, 789-803. [CrossRef] [PubMed]

74. Marquardt, J.U.; Andersen, J.B.; Thorgeirsson, S.S. Functional and genetic deconstruction of the cellular origin in liver cancer. Nat. Rev. Cancer 2015, 15, 653-667. [CrossRef] [PubMed]

75. Baba, H.A.; Wohlschlaeger, J.; Cicinnati, V.R.; Hilgard, P.; Lang, H.; Sotiropoulos, G.C.; Takeda, A.; Beckebaum, S.; Schmitz, K.J. Phosphorylation of p70S6 kinase predicts overall survival in patients with clear margin-resected hepatocellular carcinoma. Liver Int. 2009, 29, 399-405. [CrossRef] [PubMed]

76. Zhou, L.; Huang, Y.; Li, J.; Wang, Z. The mTOR pathway is associated with the poor prognosis of human hepatocellular carcinoma. Med. Oncol. 2010, 27, 255-261. [CrossRef] [PubMed]

77. Ashworth, R.E.; Wu, J. Mammalian target of rapamycin inhibition in hepatocellular carcinoma. World J. Hepatol. 2014, 6, 776-782. [CrossRef] [PubMed]

78. Scheller, T.; Hellerbrand, C.; Moser, C.; Schmidt, K.; Kroemer, A.; Brunner, S.M.; Schlitt, H.J.; Geissler, E.K.; Lang, S.A. mTOR inhibition improves fibroblast growth factor receptor targeting in hepatocellular carcinoma. Br. J. Cancer 2015, 112, 841-850. [CrossRef] [PubMed]

79. Baselga, J.; Campone, M.; Piccart, M.; Burris, H.A., III; Rugo, H.S.; Sahmoud, T.; Noguchi, S.; Gnant, M.; Pritchard, K.I.; Lebrun, F.; et al. Everolimus in postmenopausal hormone-receptor-positive advanced breast cancer. N. Engl. J. Med. 2012, 366, 520-529. [CrossRef] [PubMed]

80. Yao, J.C.; Shah, M.H.; Ito, T.; Bohas, C.L.; Wolin, E.M.; Van Cutsem, E.; Hobday, T.J.; Okusaka, T.; Capdevila, J.; de Vries, E.G.; et al. Everolimus for advanced pancreatic neuroendocrine tumors. N. Engl. J. Med. 2011, 364, 514-523. [CrossRef] [PubMed]

81. Pavel, M.E.; Hainsworth, J.D.; Baudin, E.; Peeters, M.; Horsch, D.; Winkler, R.E.; Klimovsky, J.; Lebwohl, D.; Jehl, V.; Wolin, E.M.; et al. Everolimus plus octreotide long-acting repeatable for the treatment of advanced neuroendocrine tumours associated with carcinoid syndrome (RADIANT-2): A randomised, placebo-controlled, phase 3 study. Lancet 2011, 378, 2005-2012. [CrossRef]

82. Fischer, L.; Klempnauer, J.; Beckebaum, S.; Metselaar, H.J.; Neuhaus, P.; Schemmer, P.; Settmacher, U.; Heyne, N.; Clavien, P.A.; Muehlbacher, F.; et al. A randomized, controlled study to assess the conversion from calcineurin-inhibitors to everolimus after liver transplantation-PROTECT. Am. J. Transpl. 2012, 12, 1855-1865. [CrossRef] [PubMed]

83. De Simone, P.; Nevens, F.; De Carlis, L.; Metselaar, H.J.; Beckebaum, S.; Saliba, F.; Jonas, S.; Sudan, D.; Fung, J.; Fischer, L.; et al. Everolimus with reduced tacrolimus improves renal function in de novo liver transplant recipients: A randomized controlled trial. Am. J. Transpl. 2012, 12, 3008-3020. [CrossRef] [PubMed]

84. Roat, E.; De Biasi, S.; Bertoncelli, L.; Rompianesi, G.; Nasi, M.; Gibellini, L.; Pinti, M.; Del Giovane, C.; Zanella, A.; Di Benedetto, F.; et al. Immunological advantages of everolimus versus cyclosporin A in liver-transplanted recipients, as revealed by polychromatic flow cytometry. Cytometry A 2012, 81, 303-311. [CrossRef] [PubMed]

85. Cholongitas, E.; Antoniadis, N.; Goulis, I.; Fouzas, I.; Vasiliadis, T.; Akriviadis, E.; Papanikolaou, V. Renal function improvement in liver transplant recipients after early everolimus conversion: A clinical practice cohort study in Spain. Liver Transpl. 2016, 22, 132-133. [CrossRef] [PubMed]

86. Shinohara, E.T.; Cao, C.; Niermann, K.; Mu, Y.; Zeng, F.; Hallahan, D.E.; Lu, B. Enhanced radiation damage of tumor vasculature by mTOR inhibitors. Oncogene 2005, 24, 5414-5422. [CrossRef] [PubMed]

87. Le Tourneau, C.; Faivre, S.; Serova, M.; Raymond, E. mTORC1 inhibitors: Is temsirolimus in renal cancer telling us how they really work? Br. J. Cancer 2008, 99, 1197-1203. [CrossRef] [PubMed]

88. Yamanaka, K.; Petrulionis, M.; Lin, S.; Gao, C.; Galli, U.; Richter, S.; Winkler, S.; Houben, P.; Schultze, D.; Hatano, E.; et al. Therapeutic potential and adverse events of everolimus for treatment of hepatocellular carcinoma-systematic review and meta-analysis. Cancer Med. 2013, 2, 862-871. [CrossRef] [PubMed]

89. Lee, S.C.; Kim, K.H.; Kim, O.H.; Lee, S.K.; Hong, H.E.; Choi, B.J.; Jeong, W.; Kim, S.J. Everolimus Plus Ku0063794 Regimen Promotes Anticancer Effects against Hepatocellular Carcinoma Cells through the Paradoxical Inhibition of Autophagy. Cancer Res. Treat. 2018, 50, 1023-1038. [CrossRef] [PubMed] 
90. Mehrpour, M.; Esclatine, A.; Beau, I.; Codogno, P. Autophagy in health and disease. 1. Regulation and significance of autophagy: An overview. Am. J. Physiol. Cell Physiol. 2010, 298, C776-C785. [CrossRef] [PubMed]

91. Hesse, D.; Jaschke, A.; Kanzleiter, T.; Witte, N.; Augustin, R.; Hommel, A.; Puschel, G.P.; Petzke, K.J.; Joost, H.G.; Schupp, M.; et al. GTPase ARFRP1 is essential for normal hepatic glycogen storage and insulin-like growth factor 1 secretion. Mol. Cell. Biol. 2012, 32, 4363-4374. [CrossRef] [PubMed]

(c)

(C) 2019 by the authors. Licensee MDPI, Basel, Switzerland. This article is an open access article distributed under the terms and conditions of the Creative Commons Attribution (CC BY) license (http://creativecommons.org/licenses/by/4.0/). 